$\begin{array}{cc}\text { ACADEMIA ROMÂNĂ } & \text { Rev. Roum. Chim., } \\ \mathbf{2 0 2 1}, \text { 66(2), 149-160 }\end{array}$

\title{
ETHOXY-TETHERED CALIX[4]ARENES CONTAINING P(III) SUBSTITUENTS AND TRIMETHYLSILOXY GROUPS AS BUILDING BLOCKS IN SUPRAMOLECULAR CHEMISTRY; CIS/TRANS INTRA- AND INTERMOLECULAR COMPLEXATION OF DICHLOROPLATINUM(II) FRAGMENTS
}

\author{
Ion NEDA, ${ }^{*, a, b}$ Ionel BALCU ${ }^{\mathrm{b}}$ and Corina MACARIE ${ }^{\mathrm{b}}$ \\ ${ }^{a}$ Institute for Inorganic and Analytical Chemistry of the Technical University of Braunschweig, Hagenring 30, \\ 38106 Braunschweig, Germany \\ ${ }^{\mathrm{b}}$ National Research and Development Institute for Electrochemistry and Condensed Matter, \\ Str. Dr. A. Păunescu Podeanu Nr. 144, Ro-300569 Timişoara, Roumania
}

p-tert-Butylcalix[4]arene 1 reacts with bromoethyl acetate and $\mathrm{LiAlH}_{4}$ to form the p-tert-butyltetrakis(2-hydroxyethoxy)calix[4]arene $\mathbf{8}$ bearing four ethyl-spacers at the lower rim of the calixarene. Reaction of $\mathbf{8}$ with $\mathrm{Et}_{2} \mathrm{NSiMe}_{3}$ leads to the tetrakissubstituted derivative 9. Treatment of 9 with $\mathrm{PF}_{2} \mathrm{Cl}$ gives the stable tetrakis-fluorophosphite 10, while the reaction with 2-chloro-1,3,5-trimethyl-1,3,5triaza- $2 \sigma^{3} \lambda^{3}$-phosphorin-4,6-dione furnishes the tetrakis-substituted molecule 11. When $\mathbf{1 1}$ was allowed to react with $\mathrm{SO}_{2} \mathrm{Cl}_{2}$, formation of the tetrakis(2-chloro)ethyl substituted calix[4]arene $\mathbf{1 3}$ was observed. All examined calixarene derivatives are exclusively obtained in the cone conformer.

Reaction of $\mathbf{1 1}$ with dichloro(cyclooctadiene)

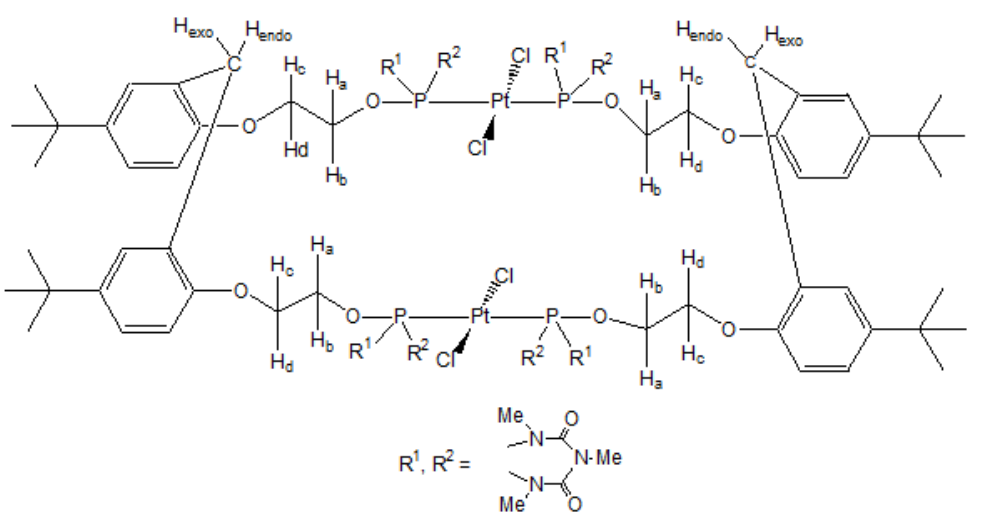

platinum(II) leads to the symmetrically four-times bridged dimmer 15, which exhibits a trans orientation of the atoms surrounding the platinum(II) atom and involves all eight phosphorus atoms in the bridges. When $\mathbf{1 0}$ was treated with $(\mathrm{COD}) \mathrm{PtCl}{ }_{2}$, the cis intermolecular complex 16 was obtained.

\section{INTRODUCTION}

The design of highly selective synthetic receptors based on calixarenes is of increasing importance in supramolecular chemistry. ${ }^{1-21}$ The great interest, that is shown in calixarenes, is due to their ability to bind guest molecules in recognition processes as sufficiently preorganized macrocycles. $^{9}$

Their different sizes and shapes, as well as the intramolecular bridging mode and functionalization at the molecules periphery influence the recognition

\footnotetext{
*Corresponding author: i.neda@tu-braunschweig.de
} 
properties of the macrocycle. ${ }^{1-27}$ A hydrophobic and a hydrophilic site, defined cavities and ordered surfaces, endow these macrocycles with special properties: selective binding of metal ions as aggregates, ${ }^{28,29}$ building blocks in supramolecular chemistry (chemo-and stereoselective recognition of carbohydrates), ${ }^{30,31}$ design of supramolecular architectures by self organisation processes, ${ }^{32}$ liquid crystals, ${ }^{33}$ sensor technology ${ }^{34}$ or visual distinction between enantiomers of biologically relevant substrates. ${ }^{35}$ Chiral calixarenes are "host" molecules capable of enantio- or diastereoselective recognition. ${ }^{36}$

Functionalization of calix[4]arene derivatives with phosphorus containing groups in more than one coordination and/or oxidation state of the phosphorus atom bonded to the lower rim of the molecules (e.g. derivatives A, B, C, D in Fig. 1) has attracted the attention of several research groups. ${ }^{2,4,537-39,40,41}$

Phosphorus(III)-containing calix[4]arenes are extensively investigated, because of their ability to act as multidentate ligands in transition metal chemistry. ${ }^{10-17,}$ 37-42 Complexation of transition metal ions by p-tert-butylcalix[4]arene- tetrakis(diphenylphosphinite) and p-tert-butylcalix [4]arenetetrakis-(dimethylphosphinite) with formation of the mono-, homodi- and heterodimetallic complexes $^{42}$ was reported. The chemistry of compounds containing PF-groups received increasing attention because, for example, fluorophosphates can be incorporated into oligodesoxyribonucleosides in such a way that they can control the growth of viruses and cells. ${ }^{43}$

It is obvious that the use of chlorodifluorophosphines as reactants can provide new fluorinecontaining groups as synthon for the synthesis of physiologic active compounds. The discovery of the cytostatic activity of the so-called "cisplatinum, $^{44}$ is important to this problem. An increased cytostatic effect (synergetic effect) of the cis- and trans-platinum(II) complexes described in this paper could be expected. Particular attention was given to the investigation of the cis/transcomplexation via NMR spectroscopy, by monitoring the bridging methylene, which can be used as spectroscopic proof to examine the cis or trans stereoisomery of the $\mathrm{PtCl}_{2}$-units attached to the $\mathrm{P} 4$ system.<smiles>CCOC1(C(C)(C)C)Cc2cc(C(C)(C)C)cc(C(C)(C)C)c2O1</smiles>

A

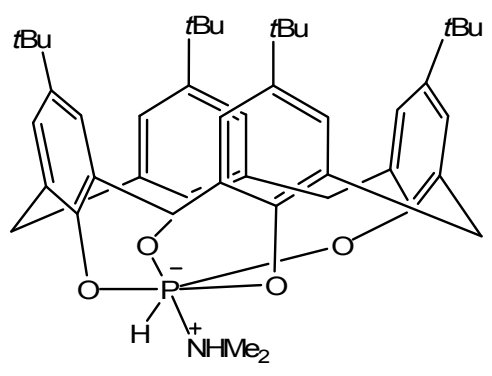

C
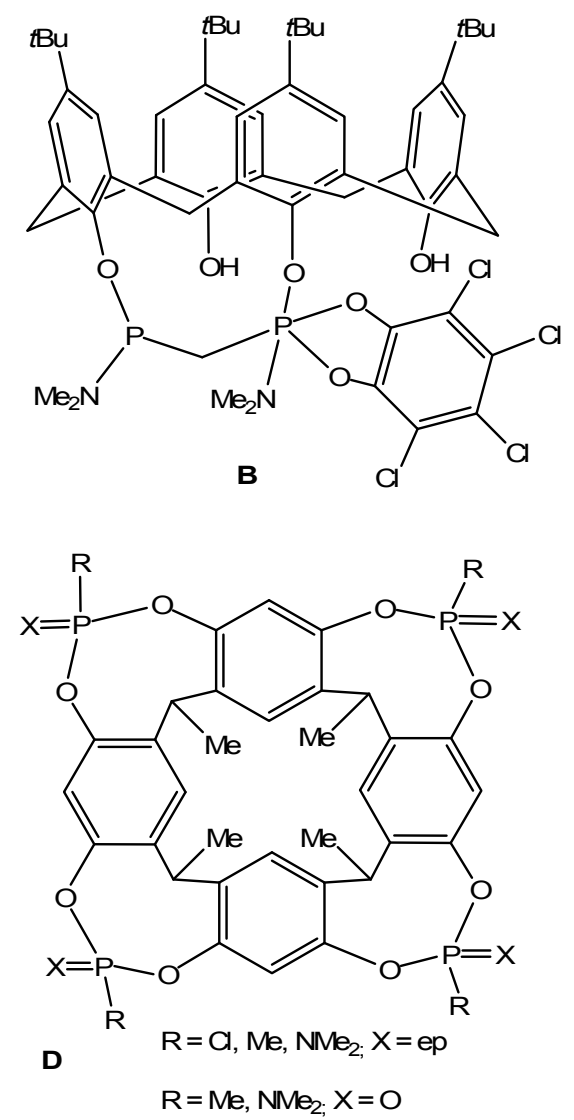

Fig. 1 - Calix[4]arene derivatives containing phosphorus(III) and phosphorus(V) atoms at the lower rim of the molecule. 

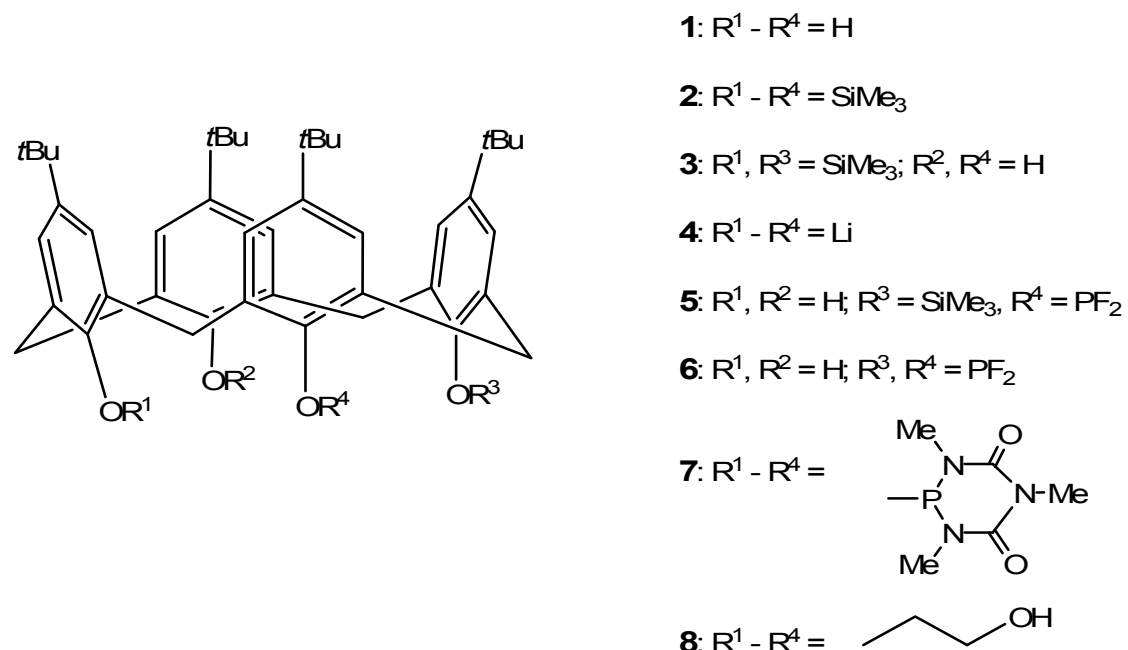

Fig. 2 - Calix[4]arene precursors used in this report.

One of the problems in calix[4]arene chemistry is the fact that they can exist in four different conformers: cone, partial cone, 1,2- and 1,3alternate. ${ }^{45,46}$ Furthermore, equilibrium reactions of these different conformers occur in solution ${ }^{46}$. Separation of the conformers is experimentally difficult or even impossible, ${ }^{10}$ but all conformers can be distinguished by their characteristic splitting patterns of the $\mathrm{ArCH}{ }_{2} \mathrm{Ar}$ signals in the ${ }^{1} \mathrm{H}$ - and ${ }^{13} \mathrm{C}$ NMR spectra. ${ }^{45,47,48}$ It is known that an unmodified p-tert-butylcalix[4]arene adopts a cone conformation because of the strong hydrogenbonding interaction among the OH-groups. ${ }^{18-20}$ Shinkai et al. described that O-substituents larger than ethyl can inhibit the rotation of the phenol unit, whereas the $\mathrm{OH}$-groups can still rotate even in tetra-tert-butyl-tris(propy-loxy)calix[4]arene derivatives. ${ }^{45}$ In a previous paper, we described the partial silylation of the $\mathrm{OH}$-groups of p-tertbutylcalix[4]arene with $\mathrm{Et}_{2} \mathrm{NSiMe}_{3}$, affording dihydroxy-bis(trimethylsilyl)calix[4]-arene $\quad \mathbf{3 .}^{10}$ Compounds obtained by reacting the calix[4]arene 1 (depicted in Fig. 2) with $\mathrm{Et}_{2} \mathrm{NSiMe}_{3}$ are of special interest as building blocks in the phosphorus functionalization of the lower rims of the calix[4]arene skeleton. Until now, it was not possible to substitute all four hydrogen atoms of the $\mathrm{OH}$-groups in $\mathbf{1}$ by trimethylsilyl groups, generating the calix[4]arene $\mathbf{2}$ as possible precursor to phosphor-rus containing calix[4]arenes. Only the dihydroxy-bis(trimethylsiloxy)calix[4]arene $\mathbf{3}$ has been reported. ${ }^{10}$

The non-existence of $\mathbf{2}$ is presumably due to steric reasons and to the strong hydrogen-bonding in $1,3,9-17$ preventing the substitution of all four hydrogen atoms at the lower rim by $\mathrm{SiMe}_{3}$ groups. Reaction of compound $\mathbf{3}$ with phosphorus(III) halides such as chlorodifluorophosphine led to only partially substituted compounds. ${ }^{10,22,23}$ Although reaction of $\mathbf{1}$ with $n$-butyl lithium furnishes the fully lithiated compound $\mathbf{4}$, only a mixture of the four conformers ${ }^{1,10,42}$ was formed, because the formation of hydrogen bonds, which stabilize only one conformer, is not possible any longer. Thus, reaction of $\mathbf{4}$ with various 2 -chloro5,6-benzo-1,3-diaza- $2 \sigma^{3} \lambda^{3}$-phosphorin-4-ones and 2-chloro-1,3,5-trimethyl-1,3,5-triaza- $2 \sigma^{3} \lambda^{3}$ -

phosphorin-4,6-dione led to mixtures of cone, partial cone and 1,2- and 1,3-alternate conformers, which were difficult to separate. ${ }^{10}$

We reported that the reaction of 7 with (COD) $\mathrm{PtCl}_{2}$ afforded an intramolecular bridged complex and that only two phosphorus atoms are trans-coordinated to the platinum atom. ${ }^{10}$ Only in case of compound 7 (see Fig. 2), the cone conformer could be separated by crystallization from acetonitrile/hexane (volume ratio 3:1).

\section{RESULTS AND DISCUSSION}

The interest in the design of artificial, supramolecular conductors by metal induced self-organization processes has increased considerably. ${ }^{37-39,}$, 54-56

This manuscript focuses on the investigation of the analogous reactions, employing conformationally frozen calix[4]arenes bearing hydroxyl groups bonded via a spacer to the lower rim of the molecule, assuring an appropriate distance of these groups from the calixarene ring system. Thus, steric effects should be minimized and substitution reactions generating completely substituted products should be facilitated. Hence, compound $\mathbf{8}$ 
was silylated with $\mathrm{Et}_{2} \mathrm{NSiMe}_{3}$ and reactions of the silylated product 9 with $\mathrm{PF}_{2} \mathrm{Cl}$ and with 2-chloro1,3,5-trimethyl-1,3,5-triaza- $\sigma^{3} \lambda^{3}$-phosphorin-4,6dione to gain compounds $\mathbf{1 0}$ and respectively $\mathbf{1 1}$ were studied. Reaction of $\mathbf{1 1}$ with $\mathrm{SO}_{2} \mathrm{Cl}_{2}$ afforded the p-tert-butyl-tetrakis(2-chloroethyl)calix[4] arene 13. Conformationally fixed derivatives $\mathbf{1 0}$, 11 and 13 represent new and significant building blocks in supramolecular chemistry. For example, the reaction of $\mathbf{8}$ with $\mathbf{1 0}$ led to the macrocycle $\mathbf{1 4}$. Reactivities of $\mathbf{1 0}$ and 11, as representative examples, are compared with those of the corresponding calix[4]arene derivatives 5-7 without spacers. ${ }^{10-17}$ Tetrakis phosphorus(III)substituted products $\mathbf{1 0}$ and $\mathbf{1 1}$ frozen in the cone conformation can be employed as unusual tetradentate ligands in transition metal complex chemistry. They were reacted with (COD) $\mathrm{PtCl}_{2}$ in order to study their complexation behaviour.

\section{Synthesis of 9-11}

A calix[4]arene with four 2-hydroxyethyl groups bonded to its lower rim (derivative 8 ) $^{49}$ was allowed to react with $\mathrm{Et}_{2} \mathrm{NSiMe}_{3}$ according to Scheme 1, furnishing in good yield compound $\mathbf{9}$, as a white solid, with a very good solubility in most common organic solvents.

All four hydrogen atoms of the terminal hydroxyl groups in $\mathbf{8}$ could be substituted by trimethylsilyl groups. In contrast to the corresponding compound 1 (illustrated in Fig. 2), steric effects do not influence the silylation reaction. The insertion of the spacer group $\mathrm{CH}_{2} \mathrm{CH}_{2} \mathrm{O}$ enabled the formation of the tetrakis(trimethylsiloxy) derivative 9, which exists at room temperature exclusively in the cone conformation. ${ }^{1} \mathrm{H}-$ and ${ }^{13} \mathrm{C}-\mathrm{NMR}$ spectroscopy, mass spectrometry and elemental analysis confirmed the formation of this product.

We are now able to present a facile functionalization of the lower rim of the tetra-tertbutylcalix-[4]arene derivative 9 with $\mathrm{PF}_{2}$ and $\mathrm{P}(\mathrm{N}(\mathrm{Me}) \mathrm{C}(=\mathrm{O}))_{2} \mathrm{NMe}$ units via ethoxy-tethered trimethylsiloxy groups.

The object of our investigation was to utilize the fully $\mathrm{PF}_{2}$ and $\mathrm{P}(\mathrm{N}(\mathrm{Me}) \mathrm{C}(=\mathrm{O}))_{2} \mathrm{NMe}$ functionalized tetra-p-tert-butyl-tetrakis(ethoxy)calix[4]arene derivatives $\mathbf{1 0}$ and $\mathbf{1 1}$ in their cone conformation for fitting $\mathrm{PtCl}_{2}$-units in the homodimetallic complex 16 (cis-intramolecular complexation) or the homotetrametallic complex 15 (transintermolecular complexation).

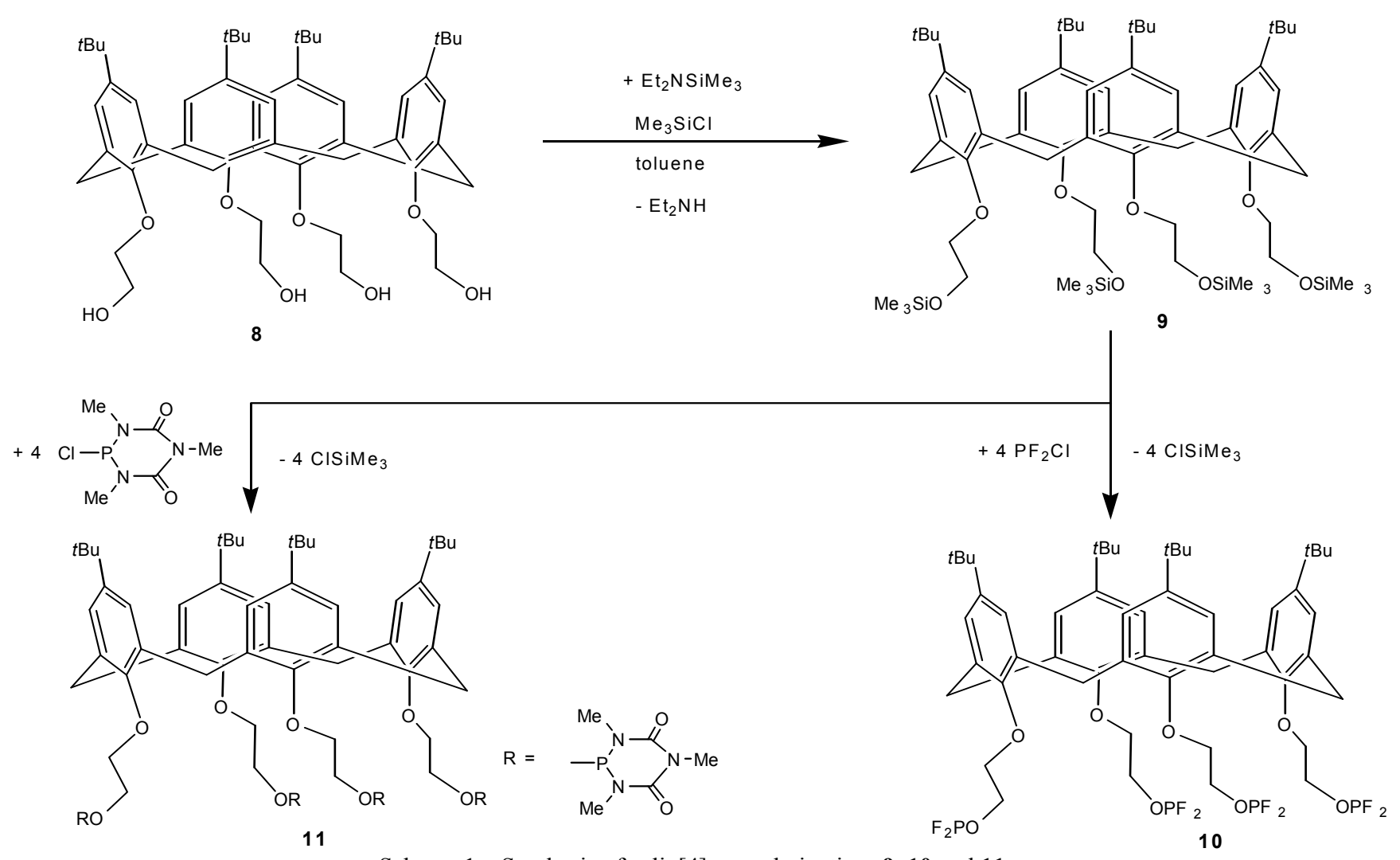

Scheme 1 - Synthesis of calix[4]arene derivatives $\mathbf{9 , 1 0}$ and $\mathbf{1 1}$. 
Reaction of 9 with chlorodifluorophosphine gave only the cone conformer of the fully $\mathrm{PF}_{2}$ functionalized calix[4]arene $\mathbf{1 0}$ (see Scheme 1). On the contrary, the reaction of $\mathrm{PF}_{2} \mathrm{Cl}$ with $\mathrm{O}, \mathrm{O}^{\prime}-$ bis(trimethylsilyl)catechole led to 1-O(difluorophosphite)-2-O-(trimethylsilyl)catechole.

The insertion of a second $\mathrm{PF}_{2}$-group via reaction with another $\mathrm{PF}_{2} \mathrm{Cl}$ molecule failed, because the substitution of the silyl group in monosubstituted O-(trimethylsilyl)catechole is slower than the formation of the cyclic product 2-fluoro-1,3,2benzodiazaphosphole. ${ }^{50,51}$ This behaviour is probably caused by the different reactivity of the phenolic and alcoholic $\mathrm{OSiMe}_{3}$-groups, and by steric reasons (distant $\mathrm{OSiMe}_{3}$-groups in $\mathbf{3}$ and $\mathbf{9}$, compared to 10). The structure of $\mathbf{1 0}$ was established by NMR and IR spectroscopy, mass spectrometry and elemental analysis.

Previously, we reported that mono- and disubstituted difluorophosphite derivatives $\mathbf{5}$ and $\mathbf{6}$ (illustrated in Fig. 2) led, by heating at $50^{\circ} \mathrm{C}$, to the formation of derivative $\mathbf{E}$ (shown in Fig. 3) and additional fluorotrimethylsilane or $\mathrm{PF}_{3}{ }^{10-17}$

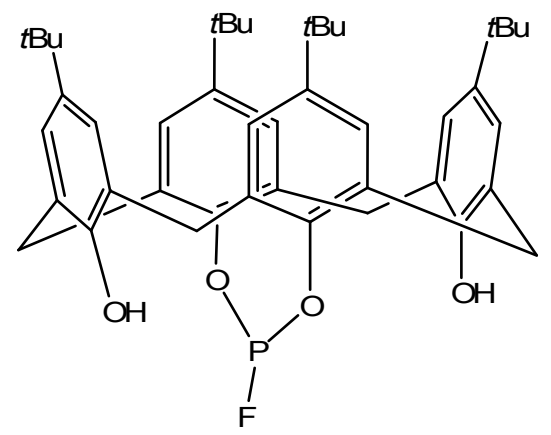

Fig. 3 - Compound $\mathbf{E}$, obtained from $\mathbf{5}$ or $\mathbf{6}$ after heating.
On the contrary, derivative $\mathbf{1 0}$ is stable in solution at $115^{\circ} \mathrm{C}$. Comparing the behaviour at heating of compound $\mathbf{1 0}$ to that of compounds $\mathbf{5}$ and $\mathbf{6}^{10-17}$ no intramolecular reaction with elimination of phosphorus trifluoride was observed. The unusual stability of $\mathbf{1 0}$ towards $\mathbf{5}$ and 6 is due to the sufficient distance to each other exhibited by all the $\mathrm{PF}_{2}$-groups. The driving force of the scrambling process can be explained satisfactorily by the thermodynamically irreversible processes theory, because formation of phosphorus trifluoride means an increase of entropy in closed systems. ${ }^{52}$

In order to determine its stability in solution, $100 \mathrm{mg}$ of $\mathbf{1 0}$ were dissolved in $1 \mathrm{ml}$ of $\mathrm{C}_{7} \mathrm{D}_{8}$ and heated to $115^{\circ} \mathrm{C}$ for 48 hours. Derivative 10 was recovered unchanged, ${ }^{1} \mathrm{H}-,{ }^{19} \mathrm{~F}-$ and ${ }^{31} \mathrm{P}-\mathrm{NMR}$ spectra recorded after heating were identical to those recorded before heating.

Reaction of 9 with 2-chloro-1,3,5-trimethyl1,3,5-triaza- $2 \sigma^{3} \lambda^{3}$-phosphorin-4,6-dione ${ }^{50}$ led, with elimination of chlorotrimethylsilane, exclusively to the cone conformer of $\mathbf{1 1}$, confirmed by the ${ }^{31} \mathrm{P}$ NMR spectrum (shows only one singlet at $\delta\left({ }^{31} \mathrm{P}\right)=$ $92.24 \mathrm{ppm})$.

\section{Reaction of 11 with $\mathrm{SO}_{2} \mathrm{Cl}_{2}$ affording 13}

When compound $\mathbf{1 1}$ was allowed to react with sulfuryl chloride, formation of $\mathbf{1 3}$ accompanied by the already known 2-chloro-2-oxo-1,3,5-trimethyl1,3,5-triaza- $2 \sigma^{3} \lambda^{4}$-phosphorin-4,6-dione $\mathbf{1 2}$ was observed $^{53}$. The reaction scheme is illustrated in Equation 1.

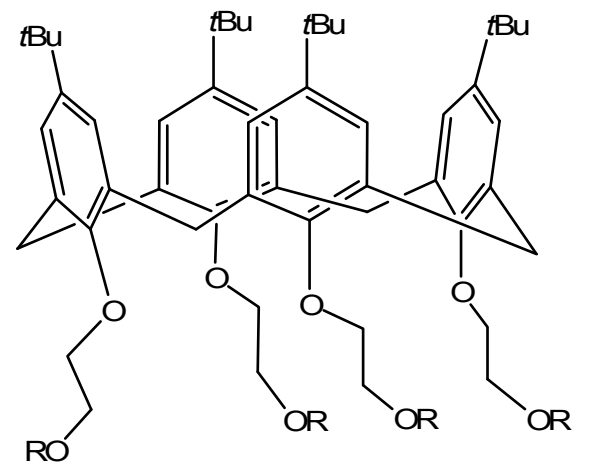<smiles>[R]=CP1N(C)C(=O)N(C)C(=O)N1C</smiles>

11

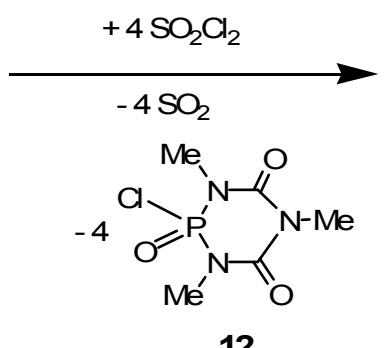

12

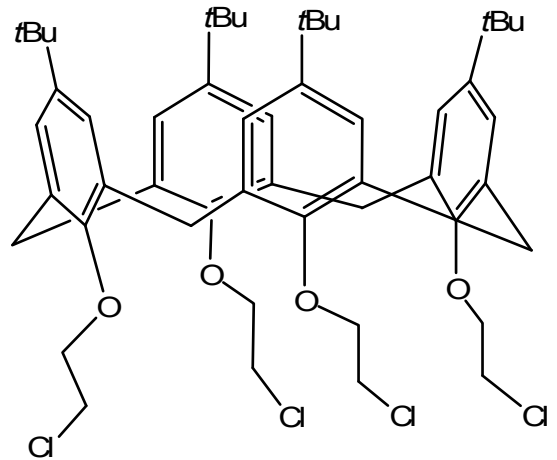

13

Equation 1 - Synthesis of calix[4]arene derivative 13. 


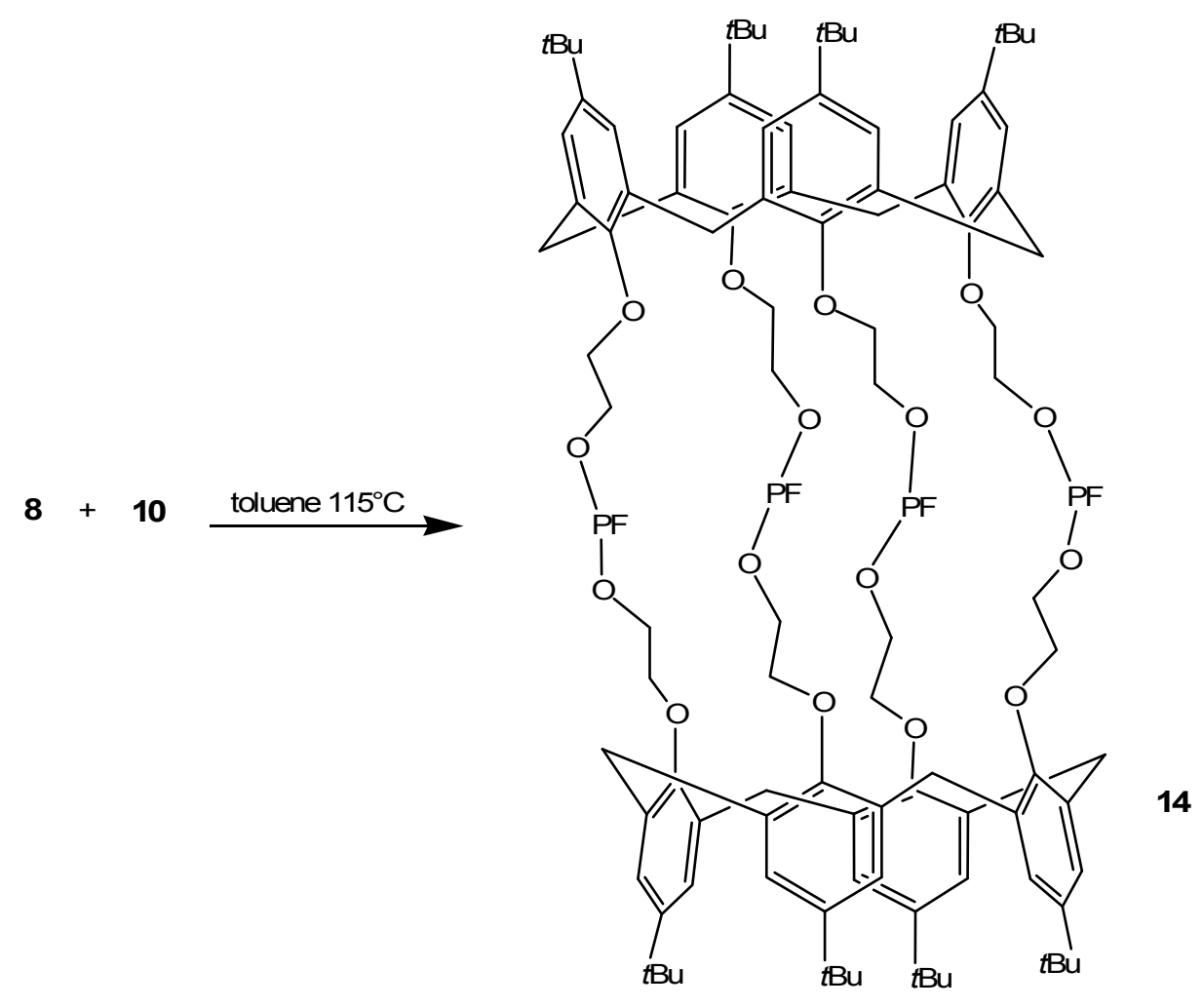

Equation 2 - Synthesis of calix[4]arene derivative $\mathbf{1 4}$.

Compound 13 was unambiguously characterized by NMR and IR spectroscopy and by elemental analysis. Calix[4]arene 13, bearing a chlorine atom directly bonded to the spacer, was found to be a stable product, existing at room temperature only in the cone conformation.

\section{Reaction of 8 with 10 affording 14}

Reaction of $\mathbf{8}$ with $\mathbf{1 0}$ in a molar ratio of $1: 1$ in toluene at $115^{\circ} \mathrm{C}$ furnished the macrocycle $\mathbf{1 4}$, according to Equation 2.

The structure of $\mathbf{1 4}$ was assigned on the basis of the ${ }^{1} \mathrm{H}-,{ }^{19} \mathrm{~F}-,{ }^{31} \mathrm{P}-\mathrm{NMR}$ and IR spectra and on FAB mass spectrometry investigation. According to NMR evidence, compound $\mathbf{1 4}$ exists in $\left(\mathrm{C}_{4}\right)$ symmetrical structure. No dynamic character was observed in toluene after heating for $12 \mathrm{~h}$ to $115^{\circ} \mathrm{C}$. The high symmetry of the molecule is illustrated particularly by plain ${ }^{1} \mathrm{H}-\mathrm{NMR}$ spectrum, where a pair of doublets is found for the methylene protons $\left(\mathrm{Ar}-\mathrm{C}_{2}-\mathrm{Ar}\right)$. The presence of an only single $v(\mathrm{PF})$ absorption band in the FT-IRspectrum at $850 \mathrm{~cm}^{-1}$ indicates only one P-F bond. Under similar experimental conditions, the FT-IR spectrum of the starting material $\mathbf{1 0}$ exhibits two $v(\mathrm{PF})$ bands, indicating the existence of two P-F bonds in the molecule. The formation of $\mathbf{1 4}$ was supported also by FAB mass spectrometry, which indicated the molecular ion. The chemical shift at $\delta\left({ }^{31} \mathrm{P}\right)=109 \mathrm{ppm}\left(\right.$ doublet, $\left.{ }^{1} \mathrm{~J}(\mathrm{PF})=1213.75 \mathrm{~Hz}\right)$ and the resonance at $\delta\left({ }^{19} \mathrm{~F}\right)=-41.65 \mathrm{ppm}$ (doublet, $\left.{ }^{1} \mathrm{~J}(\mathrm{FP})=1212.18 \mathrm{~Hz}\right)$ were attributed to the compound 14.

\section{The Assembly of Two Molecules \\ of 11 by Trans-Complexation with (COD)PtCl ${ }_{2}$ affording Compound 15}

The connection of two or more phosphorus(III)containing calix[4]arene units, by complexation of the phosphorus(III) donors to transition metal acceptors, can lead to a receptor having new properties, unknown in simple transition metal phosphine complexes.

In this paper, we present the highly symmetrical structure of the intermolecular tetrakis-bridged trans dichloroplatinum(II) complex 15 containing phosphorus(III) groups.

When 11 was allowed to react in a solution of dichlorormethane with (COD) $\mathrm{PtCl}_{2}$ in a molar ratio of 1:2, the trans-dichloroplatinum(II) dimmer 15, intramoleculary bridged by functionalized calix[4]arene units, involving all four $\sigma^{4} \lambda^{3}$ phosphorus atoms of each calix[4]arene unit in the bridges (as depicted by Equation 3), was observed. 


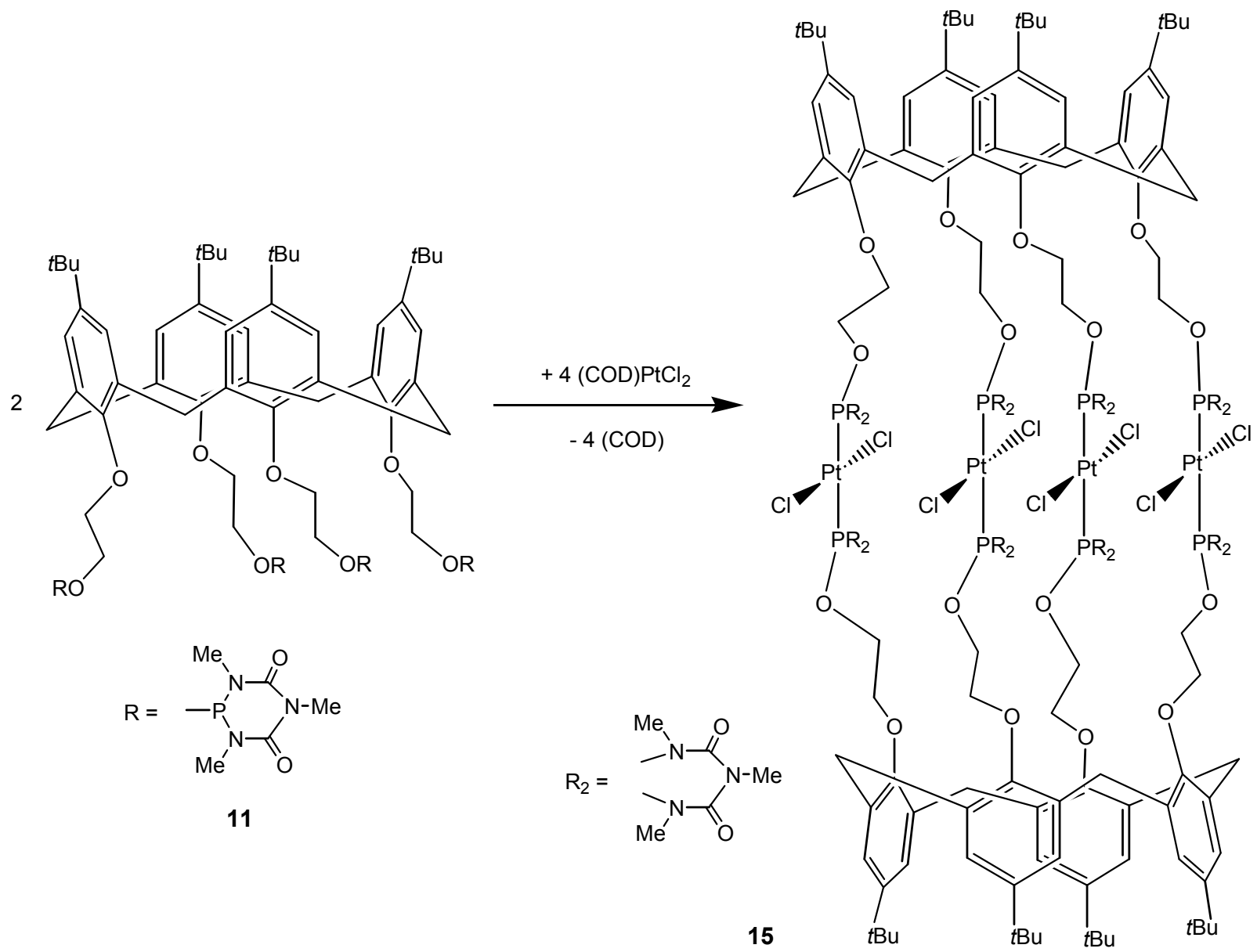

Equation 3 - Synthesis of the trans intermolecular dimeric tetranuclear complex 15 .

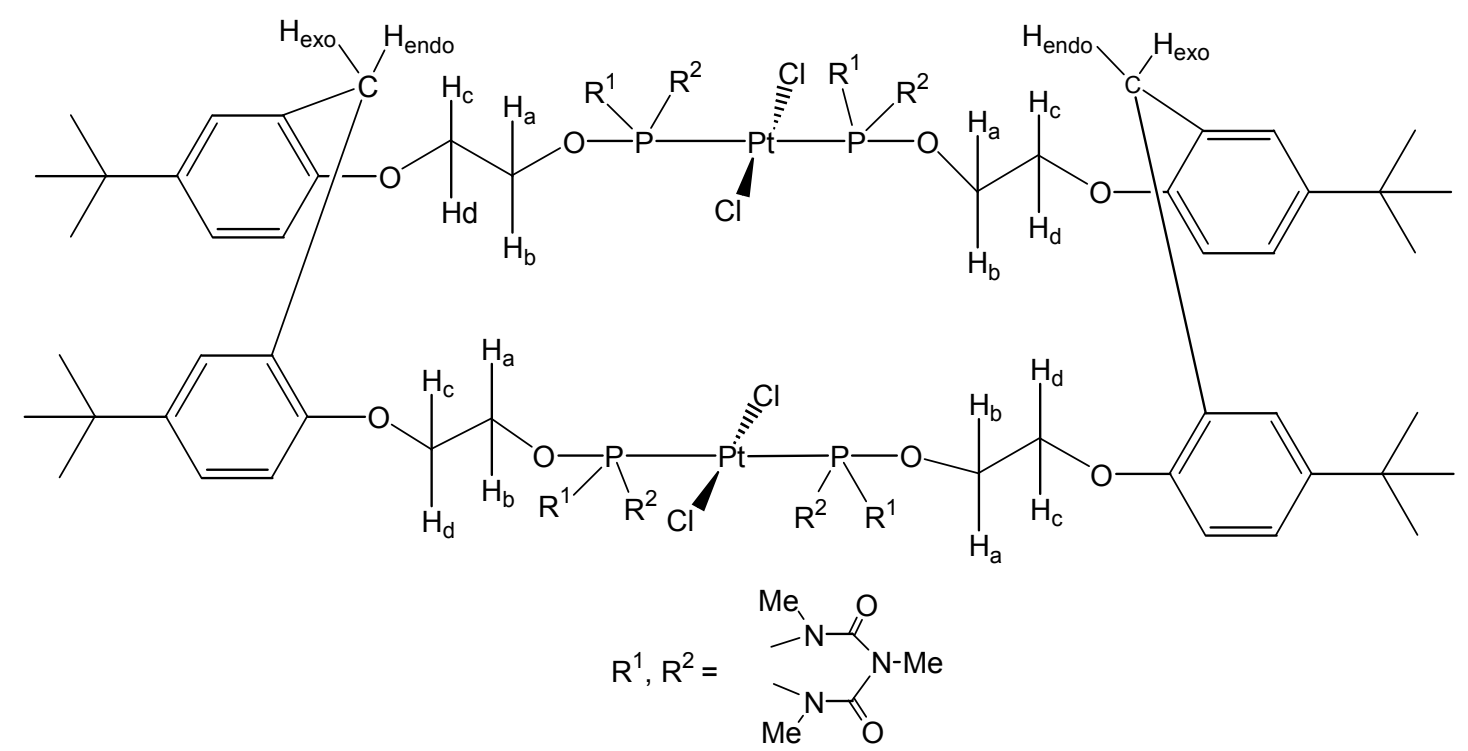

Fig. 4 - Illustration of the exo and endo protons in $\mathbf{1 5 .}$

The formation of the dimmer $\mathbf{1 5}$ does not depend on its concentration in dichloromethane. In diluted solution (100 mg in $100 \mathrm{ml}$ dichloromethane) and in concentrated solution (200 $\mathrm{mg}$ in $5 \mathrm{~mL}$ of dichloromethane), only the formation of the transdimeric complex was noticed. 
According to ${ }^{1} \mathrm{H}-,{ }^{13} \mathrm{C}$-, ${ }^{31} \mathrm{P}-\mathrm{NMR}$ evidence, 15 exists exclusively in the cone conformation and $\left(\mathrm{C}_{4}\right)$ symmetrical structure. No dynamic character was observed at room temperature in solution. The ${ }^{31} \mathrm{P}-\mathrm{NMR}$ spectrum of 15 , recorded at $20^{\circ} \mathrm{C}$ and $50^{\circ} \mathrm{C}$, exhibited one triplet at $\delta\left({ }^{31} \mathrm{P}\right)=60.4 \mathrm{ppm}$. In contrast to the results found for some bisfunctionalized tetrakis-tert-butylcalix[4]arene phosphinite derivatives, ${ }^{37-39,42}$ the intramolecular cis-dichloroplatinum(II) bridged complex was not formed.

The high symmetry of the molecule $\left(\mathrm{C}_{4}\right)$ is highlighted particularly by plain ${ }^{1} \mathrm{H}-,{ }^{13} \mathrm{C}-,{ }^{31} \mathrm{P}-\mathrm{NMR}$ spectra. The ${ }^{1} \mathrm{H}-\mathrm{NMR}$ spectrum of $\mathbf{1 5}$ reveals a pair of doublets for the $\mathrm{Ar}-\underline{\mathrm{CH}}_{\text {exo }}\left(\mathrm{H}_{\text {endo }}\right)-\mathrm{Ar}$ protons. The diastereotopicity is due to the fact that one proton is oriented out of the calixarene macrocycle (the exo proton) and the other oriented inward (the endo proton), as depicted in Fig. 4.

The endo proton is influenced by the dipolar moments of the neighbouring oxygen atoms (phenyl groups are bonded in "syn-position" in calix[4]arenes) ${ }^{42,45,47,48}$ A proton-decoupled ${ }^{13} \mathrm{C}$ NMR spectrum exhibits only one $\delta\left({ }^{13} \mathrm{C}\right)$-value for the carbon atom of the methylene group. The difference between the $\delta\left({ }^{13} \mathrm{C}\right)$-values for syn- and anti-conformation is due to steric reasons rather than electronic reasons, ${ }^{47,48}$ this is clear evidence for the cone conformation. ${ }^{47}$

The propensity of 1,3-diphosphinooxycalix[4]arenes to behave as bridging ligands capable of forming oligomeric complexes was also verified with unsymmetrically substituted diphosphinites. ${ }^{37}$ Homodimetallic [\{calix[4]$\left.\left.\left(\mathrm{PR}_{2}\right)_{4}\right\}\left(\mathrm{MCl}_{2}\right)_{2}\right](\mathrm{R}=\mathrm{Me}, \mathrm{Ph} ; \mathrm{M}=\mathrm{Pt}, \mathrm{Pd}, \mathrm{Rh})$ and heterodimetallic [\{calix[4]-( $\left.\left.\left.\mathrm{PPh}_{2}\right)_{4}\right\} \mathrm{NiCl}_{2}\left\{\mathrm{Mo}(\mathrm{CO})_{4}\right\}\right]$ were reported by Floriani. ${ }^{42}$ The cis stereochemistry around the metal atoms was described for calix[4]arenes bearing bidentate phosphorus(III) ligands with methy-lene as spacer. ${ }^{38}$

The trans arrangement around the platinum(II) atoms was deduced from ${ }^{31} \mathrm{P}-\mathrm{NMR}$ and FT-IR spectra. The presence of a single $v(\mathrm{PtCl})$ adsorption band in the FT-IR spectrum of $\mathbf{1 5}$ indicated a trans orientation of the chlorine atoms. This arrangement is supported by the fact that under similar experimental conditions two $v(\mathrm{PtCl})$ bands in the range $330-280 \mathrm{~cm}^{-1}$ were observed for the cis-dichloroplatinum(II) complex. ${ }^{38}$

It is well known that cis- and trans-coordination geometry can be distinguished by the ${ }^{1} \mathrm{~J}\left({ }^{31} \mathrm{P}^{195} \mathrm{Pt}\right)$ coupling constant. ${ }^{57}$ In case of compound $\mathbf{1 5}$, the ${ }^{1} \mathrm{~J}\left({ }^{31} \mathrm{P}^{195} \mathrm{Pt}\right)$ coupling constant of $2755.62 \mathrm{~Hz}$ confirms the trans coordination at the platinum atoms.

The dimeric structure of $\mathbf{1 5}$ was established by FAB mass spectrometry, the base peak appears at $\mathrm{m} / \mathrm{z} 4063.5\left[\mathrm{M}^{+}-\mathrm{Cl}\right]$ and the parent ion at $\mathrm{m} / \mathrm{z} 4098$ $\left[\mathrm{M}^{+}\right]$.

Compound $\mathbf{1 5}$ is stable in the solid state and in solution. In order to determine its stability in solution, $100 \mathrm{mg}$ of $\mathbf{1 5}$ were dissolved in $1 \mathrm{~mL}$ of $\mathrm{ClCH}_{2} \mathrm{CH}_{2} \mathrm{Cl}$ and heated to $80^{\circ} \mathrm{C}$ for $4 \mathrm{~h}$. 15 was recovered unchanged, fact supported by ${ }^{1} \mathrm{H}$ - and ${ }^{31} \mathrm{P}-\mathrm{NMR}$ spectroscopy. Only inclusion of COD and $\mathrm{CH}_{2} \mathrm{Cl}_{2}$ molecules were observed by ${ }^{1} \mathrm{H}-\mathrm{NMR}$ spectroscopy and mass spectrometry.

\section{Cis-Intramolecular Complexation of 10 with (COD) $\mathrm{PtCl}_{2}$}

The reaction of $\mathbf{1 0}$ with (COD) $\mathrm{PtCl}_{2}$ in a molar ratio of 1:2 afforded the cis-complex 16, according to Scheme 2, in good yield.

Contrary to the observations made when $\mathbf{1 1}$ was treated with (COD) $\mathrm{PtCl}_{2}$ (see Scheme 1), this time the cis complex was obtained. We attribute the formation of the cis-intramolecular complex $\mathbf{1 6}$ to the decreased basicity (reactivity) and steric demand of $\mathbf{1 0}$ in comparison to 11. Compound $\mathbf{1 6}$ was obtained as a crystalline solid in yields $>80 \%$.

The cis-structure of $\mathbf{1 6}$ was assigned based on the ${ }^{1} \mathrm{H}-,{ }^{19} \mathrm{~F}-,{ }^{31} \mathrm{P}-\mathrm{NMR}$ and IR spectra. In contrast to the observations made for $\mathbf{1 5}$, the room temperature ${ }^{1} \mathrm{H}-\mathrm{NMR}$ spectrum indicates a $\left(\mathrm{C}_{2}\right)$ symmetrical structure for this complex. The signals corresponding to the methylene protons were split into two pairs of doublets with coupling constants of ${ }^{2} \mathrm{~J}(\mathrm{HH})=13.00$ and $13.14 \mathrm{~Hz}$. The doublets at $\delta=3.24$ and $3.36 \mathrm{ppm}$ were assigned to the exo protons of the bridging methylene (Fig. 6), and at $\delta=4.08$ and 4.47 to the endo protons.

The two multiplets at $\delta=4.82$ and $4.89 \mathrm{ppm}$ were attributed to protons $\mathrm{H}_{\mathrm{a}}$ and $\mathrm{H}_{\mathrm{b}}$ of the $\mathrm{CH}_{a} \underline{\mathrm{H}}_{\mathrm{b}} \mathrm{OPF}_{2}$ groups. The two pairs of multiplets at $\delta=4.11,4.16,4.56$ and $4.59 \mathrm{ppm}$ were assigned to $\mathrm{H}_{\mathrm{c}}$ and $\mathrm{H}_{\mathrm{d}}$ protons of the Ar-O-C $\underline{\mathrm{H}}_{\mathrm{c}} \underline{\mathrm{H}}_{\mathrm{d}}$ groups. This nonequivalency is due to the fact that the four protons are inside the 16-membered metallocycle $\left(\mathrm{H}_{\mathrm{b}}, \mathrm{H}_{\mathrm{d}}\right)$ and two are pointing outside the metallocycle $\left(H_{a}, H_{c}\right.$, see Fig. 6). 

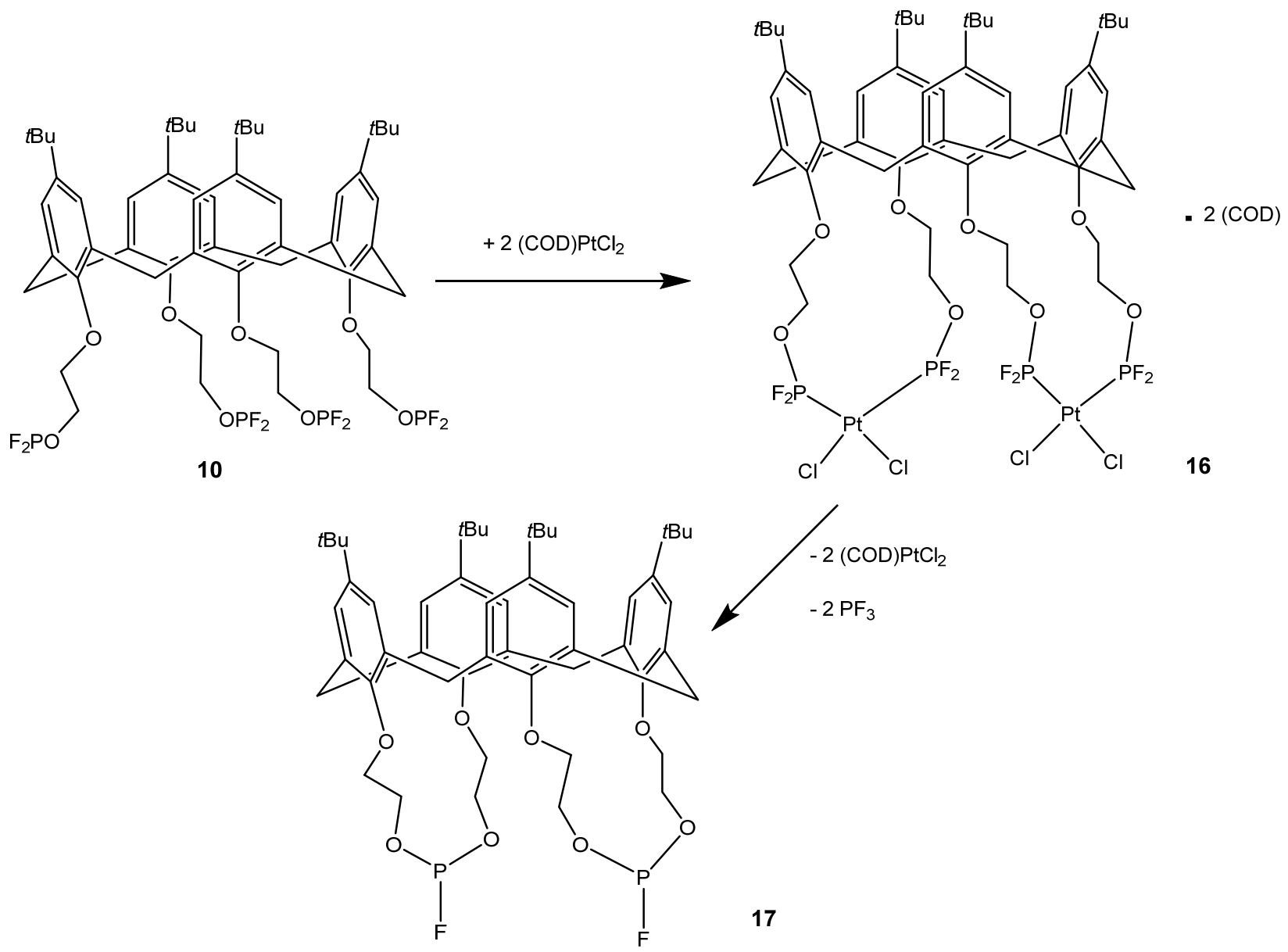

Scheme 2 - Synthesis of complex 16.

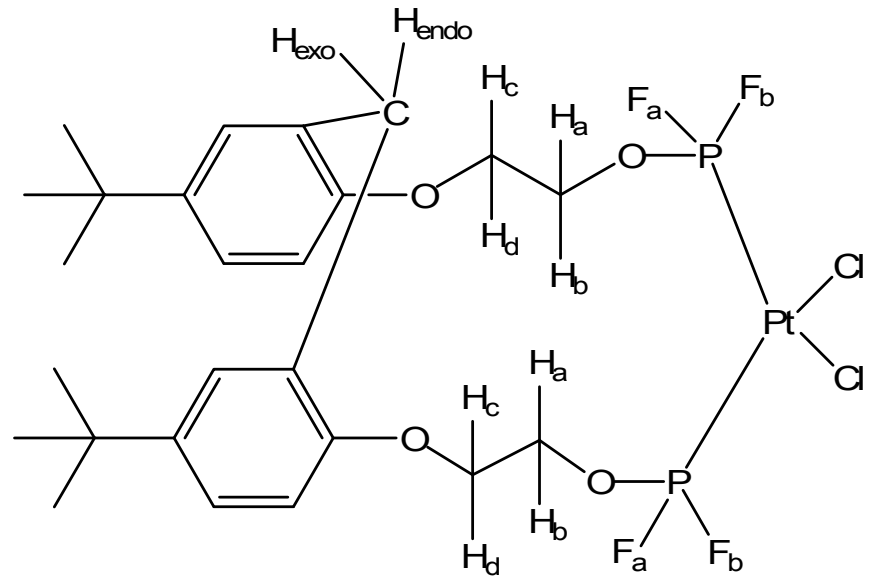

Fig. 6 - Illustration of the different protons in $\mathbf{1 6 .}$

The ${ }^{31} \mathrm{P}-\mathrm{NMR}$ spectrum of $\mathbf{1 6}$ exhibits a ddtt at $\delta=73.07 \mathrm{ppm}$ and platinum satellites with coupling constants of ${ }^{1} \mathrm{~J}\left({ }^{31} \mathrm{P}^{19} \mathrm{~F}\right)=3074.91 \mathrm{~Hz}$, ${ }^{1} \mathrm{~J}\left({ }^{31} \mathrm{P}^{195} \mathrm{Pt}\right)=2504.30 \mathrm{~Hz},{ }^{2} \mathrm{~J}(\mathrm{PP})=25.00 \mathrm{~Hz}$ and ${ }^{3} \mathrm{~J}(\mathrm{PF})=17.70 \mathrm{~Hz}$. The pronounced high-field shift, compared to the value of the free ligand $\mathbf{1 0}$ $\left(\delta\left({ }^{31} \mathrm{P}\right)=120 \mathrm{ppm}\right)$, suggests the presence of a $\sigma / \pi$ synergism. ${ }^{58}$ The ${ }^{31} \mathrm{P}$ - and ${ }^{19} \mathrm{~F}-\mathrm{NMR}$ evidence, $\left(\delta(\mathrm{ppm})=-41.35\left(\mathrm{dddt},{ }^{1} \mathrm{~J}(\mathrm{FP})=1246.50 \mathrm{~Hz}\right.\right.$, ${ }^{2} \mathrm{~J}\left({ }^{19} \mathrm{~F}^{195} \mathrm{Pt}\right)=616.20 \mathrm{~Hz},{ }^{3} \mathrm{~J}(\mathrm{FP})=25,97 \mathrm{~Hz},{ }^{4} \mathrm{~J}(\mathrm{FF})$ $=15.38 \mathrm{~Hz})$ and the typical value of the ${ }^{1} \mathrm{~J}\left({ }^{31} \mathrm{P}^{195} \mathrm{Pt}\right)$ coupling constants, indicates a cis orientation of the ligand at platinum in the square planar coordination geometry of the platinum(II) complex. The presence of two $v(\mathrm{PtCl})$ absorption bands in the FT-IR spectrum of $\mathbf{1 6}$ in the range 
$350-280 \mathrm{~cm}^{-1}$ indicated a cis orientation of the chlorine atoms. These results are similar to those described in the literature..$^{37-39}$

Compound $\mathbf{1 6}$ is neither stable in the solid state nor in solution. In order to determine its stability in solution, $100 \mathrm{mg}$ of $\mathbf{1 6}$ were dissolved in $\mathrm{CD}_{2} \mathrm{Cl}_{2}$ at room temperature. ${ }^{1} \mathrm{H}$ - and ${ }^{31} \mathrm{P}-\mathrm{NMR}$ spectra recorded after $12 \mathrm{~h}$ were not identical with those recorded after $1 \mathrm{~h}$. In contrast to $\mathbf{1 0}, \mathbf{1 5}$ was found to undergo a transformation in $\mathrm{CD}_{2} \mathrm{Cl}_{2}$ after $12 \mathrm{~h}$ at $25^{\circ}$ and respectively $40^{\circ} \mathrm{C}$ with formation of dimmer 17, (COD) $\mathrm{PtCl}_{2},{ }^{59} \quad \mathrm{PF}_{3}{ }^{60}$ and an unidentified product. The disproportionation reaction was monitored by ${ }^{31} \mathrm{P}-\mathrm{NMR}$ spectroscopy. According to the ${ }^{31} \mathrm{P}-\mathrm{NMR}$ spectrum, a mixture of two different compounds and $\mathrm{PF}_{3}{ }^{60}$ (quartet at $\left.\delta\left({ }^{31} \mathrm{P}\right)=140 \mathrm{ppm}\right)$ was formed. The chemical shift at $\delta\left({ }^{31} \mathrm{P}\right)=120 \mathrm{ppm}\left(\right.$ doublet, $\left.{ }^{1} \mathrm{~J}(\mathrm{PF})=1212.18 \mathrm{~Hz}\right)$ can be attributed to compound $\mathbf{1 7}$. The resonance at $\delta\left({ }^{31} \mathrm{P}\right)=95 \mathrm{ppm}$ (singlet) cannot be attached to a defined molecule, because only $17, \mathrm{PF}_{3}{ }^{60}$ and (COD) $\mathrm{PtCl}_{2}{ }^{59}$ could be isolated in pure form from the reaction mixture. The formation mechanism of $\mathbf{1 7}$ by an unusual transformation of $\mathbf{1 6}$ in solution at room temperature cannot be explained. A scrambling process is assumed in this case, caused by an approach of the $\mathrm{PF}_{2}$-groups by intermolecular rearrangement of the $\left(\mathrm{PF}_{2}\right)_{2} \mathrm{PtCl}_{2}$ groups (theory of thermodynamically irreversible processes ${ }^{52}$ ). This effect can be explained by weaker $\mathrm{PF}_{2}-\mathrm{Pt}$ bonds.

The FAB mass spectrometry investigation proves the instability of $\mathbf{1 6}$. The parent ion of $\mathbf{1 6}$ could not be detected, whereas that of $\mathbf{1 7}$ was observed.

\section{EXPERIMENTAL}

Experimental conditions, including NMR conditions and instruments, were as described in previous publications, e.g. ${ }^{61-69}$

NMR spectra were recorded on a Bruker AC 400 spectrometer and on a Bruker DMX 600 spectrometer with inverse probe head.

Chemical shifts (d) are given in ppm downfield from TMS. Coupling constants are given in Hz. Many assignments were made with support of DEPT, ${ }^{1} \mathrm{H}^{1} \mathrm{H}-\mathrm{COSY},{ }^{1} \mathrm{H}^{13} \mathrm{C}$ COSY, HMQC, HMBC and TOCSY experiments. Mass spectra (ESI) were recorded using a Finnigan MAT TSQ 700 triple quadrupole mass spectrometer equipped with a NanoES ion source. Elemental analyses were conducted at the Institut für Anorganische und Analytische Chemie der Technischen Universität Braunschweig. TLC was performed on silica gel 60 F254 coated foil (Merck). Preparative column chromatography was performed with silica gel 60 (63-200 mm, Merck).
"In vacuo" refers to a pressure of $c a 0.1 \mathrm{~mm} \mathrm{Hg}$ at $25^{\circ} \mathrm{C}$. Precursors: Tetrakis-(tert-butyl)-tetrakis(2-hydroxy)ethylcalix[4]arene $8 ;{ }^{49}$ 2-chloro-1,3,5-trimethyl-1,3,5-triaza- $2 \sigma^{3} \lambda^{3}$ phosphorin-4,6-dione; ${ }^{61-65} \quad$ chlorodifluorophosphine; ${ }^{32}$ dichloro(cycloocta-1,5-dien)platinum(II) (COD) $\mathrm{PtCl}_{2}{ }^{59,65}$

\section{Compound 9}

A mixture of $3.0 \mathrm{~g}(20.7$ mmole $)$ of diethylaminotrimethylsilane and a catalytic amount of chlorotrimethylsilane $(0.05 \mathrm{~mL})$ was added, at room temperature, dropwise to a solution of $3.0 \mathrm{~g}$ (3.6 mmole) of $\mathbf{8}$ in $50 \mathrm{~mL}$ toluene. The reaction mixture was stirred for $16 \mathrm{~h}$ at $60-80^{\circ} \mathrm{C}$. Solvent and volatile components were removed in vacuo. The remaining colourless solid showed no impurities in the ${ }^{1} \mathrm{H}$ - and ${ }^{13} \mathrm{C}-\mathrm{NMR}$ spectra. Yield: $3.2 \mathrm{~g}(80 \%)$, m.p. $188^{\circ} \mathrm{C}$.

${ }^{1} \mathrm{H}-\mathrm{NMR}\left(\mathrm{CD}_{2} \mathrm{Cl}_{2}\right): \delta(\mathrm{ppm})=0.13\left(\mathrm{~s}, 36 \mathrm{H}, \mathrm{Si}\left(\mathrm{CH}_{3}\right)_{3}\right)$, 1.07 (s, 36H, $\left.\left(\mathrm{CH}_{3}\right)_{3} \mathrm{C}\right), 3.09\left(\mathrm{~d}, 4 \mathrm{H},{ }^{2} \mathrm{~J}(\mathrm{HH})=12.56 \mathrm{~Hz}, \mathrm{Ar}-\right.$ $\left.\mathrm{C}_{\mathrm{H}^{1}} \mathrm{H}^{2}-\mathrm{Ar}\right), 4.03\left(\mathrm{~m}, 16 \mathrm{H}, \mathrm{OC}_{\mathrm{H}_{2}} \underline{\mathrm{H}}_{2} \mathrm{O}\right), 4.41\left(\mathrm{~d}, 4 \mathrm{H},\left({ }^{2} \mathrm{~J}(\mathrm{HH})\right.\right.$ $\left.=12.54 \mathrm{~Hz}, \mathrm{Ar}-\mathrm{CH}^{1} \underline{\mathrm{H}}^{2}-\mathrm{Ar}\right), 6.75(\mathrm{~s}, 8 \mathrm{H}$, aromatic $\mathrm{H}) .{ }^{13} \mathrm{C}-$ $\operatorname{NMR}\left(\mathrm{CD}_{2} \mathrm{Cl}_{2}\right): \delta(\mathrm{ppm})=-0.23\left(\mathrm{~s}, \mathrm{Si}\left(\underline{\mathrm{CH}}_{3}\right)_{3}\right), 31.55(\mathrm{~s}, \mathrm{Ar}-$ $\left.\underline{\mathrm{CH}}_{2}-\mathrm{Ar}\right), 31.63$ (s, $\left.\mathrm{C}\left(\underline{\mathrm{CH}}_{3}\right)_{3}\right), 34.12\left(\mathrm{~s}, \underline{\mathrm{C}}\left(\mathrm{CH}_{3}\right)_{3}\right), 61.94$ and $75.91\left(2 \mathrm{~s}, \mathrm{O}_{\underline{C}} \mathrm{H}_{2} \mathrm{CH}_{2} \mathrm{O}\right), 125.39-153.95\left(\mathrm{~m}_{6} \mathrm{H}_{2}\right)$. EI-MS: $\mathrm{m} / \mathrm{z}(\%): 1114(46)\left[\mathrm{M}^{+}\right], 1041$ (10) $\left[\mathrm{M}^{+}-\mathrm{SiMe}_{3}\right], 997$ (18) $\left[\mathrm{M}^{+}-\mathrm{OCH}_{2} \mathrm{CH}_{2} \mathrm{OSiMe}_{3}\right], 117$ (75) $\left[\mathrm{OCH}_{2} \mathrm{CH}_{2} \mathrm{OSiMe}_{3}{ }^{+}\right], 73$ (100) $\left[\mathrm{SiMe}_{3}{ }^{+}\right] . \mathrm{C}_{64} \mathrm{H}_{104} \mathrm{O}_{8} \mathrm{Si}_{4}$ (1113.87): calcd. C 69.01, H 9.41; found C 69.02, H 9.44.

\section{Compound 10}

In a heavy-walled glass tube, fitted with a Teflon ${ }^{\mathbb{B}}$ stepcock, a solution of $1.0 \mathrm{~g}(0.9$ mmole $)$ of 9 in $25 \mathrm{ml}$ dichloromethane was cooled at $-196^{\circ} \mathrm{C}$. Subsequently, $1.0 \mathrm{~g}$ (9.6 mmole) of chlorodifuoro-phosphine was condensed onto the solution. The reaction mixture was allowed to warm up to room temperature over $1 \mathrm{~h}$ and was stirred overnight at this temperature. Solvent and all volatile compounds were removed in vacuo and the remaining colourless solid was dried in vacuo. Yield: $0.78 \mathrm{~g}(79 \%)$; m.p. $134-136^{\circ} \mathrm{C}$.

${ }^{1} \mathrm{H}-\mathrm{NMR}\left(\mathrm{CD}_{2} \mathrm{Cl}_{2}\right): \delta(\mathrm{ppm})=1.09\left(\mathrm{~s}, 36 \mathrm{H},\left(\mathrm{C}_{3}\right)_{3} \mathrm{C}\right)$, $3.21\left(\mathrm{~d}, 4 \mathrm{H},{ }^{2} \mathrm{~J}(\mathrm{HH})=12.7 \mathrm{~Hz}, \mathrm{Ar}-\mathrm{CH}^{1} \mathrm{H}^{2}-\mathrm{Ar}\right), 4.15(\mathrm{t}, 8 \mathrm{H}$, $\left.{ }^{3} \mathrm{~J}(\mathrm{HH})=5.6 \mathrm{~Hz}, \mathrm{OCH}_{2} \mathrm{CH}_{2} \mathrm{OPF}_{2}\right), 4.37\left(\mathrm{~d}, 4 \mathrm{H},\left({ }^{2} \mathrm{~J}(\mathrm{HH})=\right.\right.$ $\left.12.7 \mathrm{~Hz}, \mathrm{Ar}-\mathrm{CH}^{1} \underline{\mathrm{H}}^{2}-\mathrm{Ar}\right), 4.50-4.59\left(\mathrm{~m}, 8 \mathrm{H}, \mathrm{OCH}_{2} \underline{\mathrm{C}}_{2} \mathrm{OPF}_{2}\right)$, $6.84(\mathrm{~s}, 8 \mathrm{H}$, aromatic $\mathrm{H}) \cdot{ }^{13} \mathrm{C}-\mathrm{NMR}\left(\mathrm{CD}_{2} \mathrm{Cl}_{2}\right): \delta(\mathrm{ppm})=31.11$ (s, Ar- $\left.\underline{\mathrm{CH}}_{2}-\mathrm{Ar}\right), 31.50\left(\mathrm{~s}, \mathrm{C}\left(\underline{\mathrm{CH}}_{3}\right)_{3}\right), 34.16\left(\mathrm{~s}, \underline{\mathrm{C}}\left(\mathrm{CH}_{3}\right)_{3}\right), 62.58$ $\left(\mathrm{m}, \quad \mathrm{OCH}_{2} \mathrm{CH}_{2} \mathrm{OPF}_{2}\right), \quad 73.61 \quad\left(\mathrm{~d},{ }^{3} \mathrm{~J}(\mathrm{PC})=3.10 \mathrm{~Hz}\right.$, $\left.\mathrm{OCH}_{2} \mathrm{CH}_{2} \mathrm{OPF}_{2}\right), \quad 125.72-152.94\left(\mathrm{~m}, \mathrm{C}_{6} \mathrm{H}_{2}\right) .{ }^{19} \mathrm{~F}-\mathrm{NMR}$ $\left(\mathrm{CD}_{2} \mathrm{Cl}_{2}\right): \delta(\mathrm{ppm})=-48.9\left(\mathrm{~d},{ }^{1} \mathrm{~J}(\mathrm{FP})=1290.7 \mathrm{~Hz}\right) .{ }^{31} \mathrm{P}-\mathrm{NMR}$ $\left(\mathrm{CD}_{2} \mathrm{Cl}_{2}\right): \delta(\mathrm{ppm})=114.8\left(\mathrm{t},{ }^{1} \mathrm{~J}(\mathrm{PF})=1290.7 \mathrm{~Hz}\right) . \mathrm{IR}(\mathrm{KBr})$ : $\mathrm{v}_{(\mathrm{as})}=790 \mathrm{~cm}^{-1}, \mathrm{v}_{(\mathrm{s})}=810 \mathrm{~cm}^{-1}\left(\mathrm{PF}_{2}\right)$. EI-MS: $\mathrm{m} / \mathrm{z}(\%): 1096$ (100) $\left[\mathrm{M}^{+}\right], 1011$ (2) $\left[\mathrm{M}^{+}-\mathrm{OPF}_{2}\right], 983$ (2) $\left[\mathrm{M}^{+}-\mathrm{CH}_{2} \mathrm{CH}_{2} \mathrm{OPF}_{2}\right]$, $113(10)\left[\mathrm{CH}_{2} \mathrm{CH}_{2} \mathrm{OPF}_{2}^{+}\right], 57(62)\left[\mathrm{C}\left(\mathrm{CH}_{3}\right)^{+}\right] \cdot \mathrm{C}_{52} \mathrm{H}_{68} \mathrm{~F}_{8} \mathrm{O}_{8} \mathrm{P}_{4}$ (1096.99): calcd. C 56.94, H 6.25; found C 56.87, H 6.54.

\section{Compound 11}

To a solution of $1.0 \mathrm{~g}(0.90 \mathrm{mmole})$ of 9 in $15 \mathrm{ml}$ dichloromethane was added dropwise (room temperature, 30 $\mathrm{min})$ a solution of $0.57 \mathrm{~g}$ (3.60 mmole) of 2-chloro-1,3,5trimethyl-1,3,5-triaza- $2 \sigma^{3} \lambda^{3}$-phosphorin-4,6-dione in $5 \mathrm{~mL}$ dichloromethane. The solution was stirred for 1 day at room tempera-ture. Solvent and all volatile products were removed in vacuo and the residue was washed three times with $10 \mathrm{~mL}$ diethyl ether. The remaining colourless solid was dried in vacuo. Yield: $1.16 \mathrm{~g}(86 \%)$; m.p. $228-230^{\circ} \mathrm{C}$. 
${ }^{1} \mathrm{H}-\mathrm{NMR}\left(\mathrm{CD}_{2} \mathrm{Cl}_{2}\right): \delta(\mathrm{ppm})=1.06\left(\mathrm{~s}, 36 \mathrm{H},\left(\mathrm{CH}_{3}\right)_{3} \mathrm{C}\right)$, $3.06\left(\mathrm{~d}, 24 \mathrm{H},{ }^{3} \mathrm{~J}(\mathrm{HH})=11.81 \mathrm{~Hz},\left(\mathrm{CH}_{3}\right) \mathrm{NP}\right), 3.19(\mathrm{~s}, 12 \mathrm{H}$, $\left.\mathrm{CH}_{3} \mathrm{~N}(\mathrm{C}(=\mathrm{O}))_{2}\right), 4.23\left(\mathrm{~d}, 4 \mathrm{H},{ }^{2} \mathrm{~J}(\mathrm{HH})=12.75 \mathrm{~Hz}, \mathrm{Ar}-\mathrm{CH}^{1} \mathrm{H}^{2}-\right.$ Ar), $3.90-4.15$ (m, br, $20 \mathrm{H}, \mathrm{OCH}_{2} \mathrm{CH}_{2} \mathrm{O}$ and $\mathrm{Ar}-\mathrm{CH}^{1} \underline{\mathrm{H}}^{2}-\mathrm{Ar}$ ), $6.77(\mathrm{~s}, 8 \mathrm{H}$, aromatic $\mathrm{H}) \cdot{ }^{13} \mathrm{C}-\mathrm{NMR}\left(\mathrm{CD}_{2} \mathrm{Cl}_{2}\right): \delta(\mathrm{ppm})=30.34$ $\left(\mathrm{s}, \quad\left(\underline{\mathrm{CH}}_{3}\right) \mathrm{N}(\mathrm{C}(=\mathrm{O}))_{2}\right), \quad 31.34 \quad\left(\mathrm{~s}, \quad \mathrm{Ar}-\underline{\mathrm{CH}}_{2}-\mathrm{Ar}\right), 31.48 \quad(\mathrm{~s}$, $\left.\mathrm{C}\left(\mathrm{CH}_{3}\right)_{3}\right), 31.50\left(\mathrm{~d},{ }^{2} \mathrm{~J}(\mathrm{PC})=28.87 \mathrm{~Hz},\left(\underline{\mathrm{CH}}_{3} \mathrm{~N}\right)_{2} \mathrm{P}\right), 34.12(\mathrm{~s}$, $\left.\mathrm{C}\left(\mathrm{CH}_{3}\right)_{3}\right), 63.59\left(\mathrm{~s}, \mathrm{Ar}-\mathrm{OCH}_{2} \mathrm{CH}_{2}\right), 73.73\left(\mathrm{~d},{ }^{2} \mathrm{~J}(\mathrm{PC})=3.32\right.$ $\left.\mathrm{Hz}, \mathrm{OCH}_{2} \mathrm{CH}_{2} \mathrm{OP}\right), 125.32-152.84\left(\mathrm{~m}, \underline{\mathrm{C}}_{6} \mathrm{H}_{2}\right), 153.53$ (d, $\left.{ }^{2} \mathrm{~J}(\mathrm{PC})=9.89 \mathrm{~Hz}, \underline{\mathrm{C}}(=\mathrm{O})\right) \cdot{ }^{31} \mathrm{P}-\mathrm{NMR}\left(\mathrm{CD}_{2} \mathrm{Cl}_{2}\right): \delta(\mathrm{ppm})=$ 94.98 (s). IR $(\mathrm{KBr}): v=1620-1670 \mathrm{~cm}^{-1}(\mathrm{C}(=\mathrm{O}))$. EI-MS: $\mathrm{m} / \mathrm{z}(\%): 1518(60)\left[\mathrm{M}^{+}\right], 1344(40)\left[\mathrm{M}^{+}-\mathrm{MeN}(\mathrm{CONMe})_{2} \mathrm{P}\right]$, $1316(100)\left[\mathrm{M}^{+}-\mathrm{MeN}(\mathrm{CONMe})_{2} \mathrm{PCH}_{2} \mathrm{CH}_{2} \mathrm{O}\right], 1170$ (20) $\left[\mathrm{M}^{+}-\right.$ $\left.2 \mathrm{MeN}(\mathrm{CONMe})_{2} \mathrm{P}\right], 996(90)\left[\mathrm{M}^{+}-3 \mathrm{MeN}(\mathrm{CONMe})_{2} \mathrm{P}\right], 174$ (90) $\left[\mathrm{MeN}(\mathrm{CONMe})_{2} \mathrm{P}^{+}\right] \cdot \mathrm{C}_{72} \mathrm{H}_{104} \mathrm{~N}_{12} \mathrm{O}_{16} \mathrm{P}_{4}$ (1517.57): calcd. C 56.98, H 6.90, N 11.07; found C 57.25, H 7.00, N 10.55.

\section{Compound 13}

Equimolar amounts of $\mathbf{1 1}(1.0 \mathrm{~g}, 0.66 \mathrm{mmole})$ and $\mathrm{SO}_{2} \mathrm{Cl}_{2}$ $(0.09 \mathrm{~g}, 0.66 \mathrm{mmole})$ in $20 \mathrm{~mL}$ dichloromethane were stirred for 2 days at room temperature. Subsequently, the solvent and all volatile compounds were removed in vacuo. The remaining colourless solid was washed three times with $20 \mathrm{ml}$ portions of diethyl ether and then dried in vacuo. The combined etheric solutions were concentrated in vacuo to a volume of ca. $20 \mathrm{ml}$ and kept at $-20^{\circ} \mathrm{C}$ for 1 day, Yield: $78 \%$; dec. $216-218^{\circ} \mathrm{C}$.

${ }^{1} \mathrm{H}-\mathrm{NMR}\left(\mathrm{CDCl}_{3}\right): \delta(\mathrm{ppm})=1.07\left(\mathrm{~s}, 36 \mathrm{H},\left(\mathrm{CH}_{3}\right)_{3} \mathrm{C}\right), 3.18$ $\left(\mathrm{d}, 4 \mathrm{H},{ }^{2} \mathrm{~J}(\mathrm{HH})=12.08 \mathrm{~Hz}, \operatorname{Ar}-\mathrm{CH}^{1} \mathrm{H}^{2}-\mathrm{Ar}\right), 4.02-4.07(\mathrm{~m}$, $\left.16 \mathrm{H}, \mathrm{OCH}_{2} \mathrm{CH}_{2} \mathrm{Cl}\right), 4.38\left(\mathrm{~d}, 4 \mathrm{H},{ }^{2} \mathrm{~J}(\mathrm{HH})=12.84 \mathrm{~Hz}, \mathrm{Ar}-\right.$ $\mathrm{CH}^{1} \underline{\mathrm{H}}^{2}$-Ar), 7.24 (s, 8H, aromatic $\left.\mathrm{H}\right) .{ }^{13} \mathrm{C}-\mathrm{NMR}\left(\mathrm{CDCl}_{3}\right): \delta$ $(\mathrm{ppm})=30.95\left(\mathrm{~s}, \mathrm{Ar}-\underline{\mathrm{CH}}_{2}-\mathrm{Ar}\right), 31.38\left(\mathrm{~s}, \mathrm{C}\left(\underline{\mathrm{CH}}_{3}\right)_{3}\right), 33.91$ (s, $\left.\underline{\mathrm{C}}\left(\mathrm{CH}_{3}\right)_{3}\right), 42.48\left(\mathrm{~s}, \mathrm{OCH}_{2} \mathrm{CH}_{2} \mathrm{Cl}\right), 74.70\left(\mathrm{~s}, 4 \mathrm{C}, \mathrm{O}_{2} \mathrm{CH}_{2} \mathrm{CH}_{2} \mathrm{Cl}\right)$, $125.35-152.31\left(\mathrm{~m}, \mathrm{C}_{6} \mathrm{H}_{2}\right)$. IR $(\mathrm{KBr}): v=759.36 \mathrm{~cm}^{-1}\left(\mathrm{CH}_{2-}\right.$ Cl). $\mathrm{C}_{52} \mathrm{H}_{68} \mathrm{Cl}_{4} \mathrm{O}_{4}$ (898.39): calcd. C 69.48, $\mathrm{H}$ 7.57; found $\mathrm{C}$ 68.68, H 7.59.

\section{Compound 14}

Reaction of $\mathbf{8}$ with $\mathbf{1 0}$ in a molar ratio of 1:1 in toluene at $115^{\circ} \mathrm{C}$ furnished the macrocycle 14 .

${ }^{1} \mathrm{H}-\mathrm{NMR}\left(\mathrm{CD}_{2} \mathrm{Cl}_{2}\right): \delta(\mathrm{ppm})=1.05\left(\mathrm{~s}, 72 \mathrm{H},\left(\mathrm{CH}_{3}\right)_{3} \mathrm{C}\right), 3.21(\mathrm{~d}$, $\left.8 \mathrm{H},{ }^{2} \mathrm{~J}(\mathrm{HH})=12.6 \mathrm{~Hz}, \mathrm{Ar}-\mathrm{CH}^{1} \mathrm{H}^{2}-\mathrm{Ar}\right)$,

$4.35\left(\mathrm{~d}, 8 \mathrm{H},\left({ }^{2} \mathrm{~J}(\mathrm{HH})=12.7 \mathrm{~Hz}, \mathrm{Ar}-\mathrm{CH}^{1} \underline{\mathrm{H}}^{2}-\mathrm{Ar}\right), 4.18(\mathrm{t}, 16 \mathrm{H}\right.$, $\left.{ }^{3} \mathrm{~J}(\mathrm{HH})=5.8 \mathrm{~Hz}, \mathrm{OCH}_{2} \mathrm{CH}_{2} \mathrm{OPF}\right), 4.30-4.50(\mathrm{~m}, 16 \mathrm{H}$, $\left.\mathrm{OCH}_{2} \mathrm{CH}_{2} \mathrm{OPF}\right),{ }^{13} \mathrm{C}-\mathrm{NMR}\left(\mathrm{CD}_{2} \mathrm{Cl}_{2}\right): \delta(\mathrm{ppm})=31.11(\mathrm{~s}, \mathrm{Ar}-$ $\left.\mathrm{CH}_{2}-\mathrm{Ar}\right), 31.50\left(\mathrm{~s}, \mathrm{C}\left(\mathrm{CH}_{3}\right)_{3}\right), 34.16\left(\mathrm{~s}, \mathrm{C}\left(\mathrm{CH}_{3}\right)_{3}\right), 60.28(\mathrm{~m}$, $\left.\mathrm{OCH}_{2} \mathrm{CH}_{2} \mathrm{OPF}\right), 70.30\left(\mathrm{~d},{ }^{3} \mathrm{~J}(\mathrm{PC})=3.10 \mathrm{~Hz}, \mathrm{OCH}_{2} \mathrm{CH}_{2} \mathrm{OPF}\right)$, $126.72-151.94\left(\mathrm{~m}, \mathrm{C}_{6} \mathrm{H}_{2}\right),{ }^{19} \mathrm{~F}-\mathrm{NMR}\left(\mathrm{CD}_{2} \mathrm{Cl}_{2}\right): \delta(\mathrm{ppm})=$ $41.65\left(\mathrm{~d},{ }^{1} \mathrm{~J}(\mathrm{FP})=1212.18 \mathrm{~Hz}\right) .{ }^{31} \mathrm{P}-\mathrm{NMR}\left(\mathrm{CD}_{2} \mathrm{Cl}_{2}\right): \delta(\mathrm{ppm})=$ $109 \mathrm{ppm}\left(\mathrm{d},{ }^{1} \mathrm{~J}(\mathrm{PF})=1213.75 \mathrm{~Hz}\right) . \quad \mathrm{IR}(\mathrm{KBr}): \mathrm{v}_{(\mathrm{s})}=850 \mathrm{~cm}^{-1}$ (PF); EI-MS: m/z (\%): 1842 (100) $\left[\mathrm{M}^{+}\right], 1748$ (2) $\left[\mathrm{M}^{+}-\right.$ $\left.\mathrm{CH}_{2} \mathrm{CH}_{2} \mathrm{OPF}\right], 94$ (10) $\left[\mathrm{CH}_{2} \mathrm{CH}_{2} \mathrm{OPF}^{+}\right], 84(62)\left[\mathrm{C}\left(\mathrm{CH}_{3}\right)_{3}{ }^{+}\right]$. $\mathrm{C}_{104} \mathrm{H}_{136} \mathrm{~F}_{4} \mathrm{O}_{16} \mathrm{P}_{4}$ (1842.08): calcd. C 66.80, H 7.44; found $\mathrm{C}$ 65.87, H 6.95 .

\section{Compound 15}

A solution of $200 \mathrm{mg}(0.53 \mathrm{mmole})(\mathrm{COD}) \mathrm{PtCl}_{2}$ in $5 \mathrm{ml}$ $\mathrm{CH}_{2} \mathrm{Cl}_{2}$ was added dropwise at $0^{\circ} \mathrm{C}$ to a solution of $111.6 \mathrm{~g}$ $(0.26 \mathrm{mmole})$ in dichloromethane. The reaction mixture was stirred for $16 \mathrm{~h}$ at room temperature. The solvent was removed in vacuo and the residue was washed three times with small amounts of ice cold diethyl ether and hexane. The remaining colourless solid was recrystallized from dichloromethane/hexane. Yield: $1.61 \mathrm{~g}(75 \%)$; dec. $260-265^{\circ} \mathrm{C}$.

${ }^{1} \mathrm{H}-\mathrm{NMR}\left(\mathrm{CD}_{2} \mathrm{Cl}_{2}\right): \delta(\mathrm{ppm})=1.00\left(\mathrm{~s}, 72 \mathrm{H},\left(\mathrm{C}_{3}\right)_{3} \mathrm{C}\right)$, $2.36\left(\mathrm{~m}, 32 \mathrm{H}, \mathrm{CH}_{2} \mathrm{CH}_{2}\right.$ of $\left.\mathrm{COD}\right), 2.95\left(\mathrm{~d}, 12 \mathrm{H},{ }^{3} \mathrm{~J}(\mathrm{PH})=10.23\right.$ $\left.\mathrm{Hz},\left(\mathrm{C}^{1} \underline{\mathrm{H}}_{3}\right) \mathrm{NP}\right), 3.01\left(\mathrm{~d}, 8 \mathrm{H},{ }^{2} \mathrm{~J}(\mathrm{HH})=11.69, \mathrm{Ar}^{-\mathrm{CH}_{\text {exo }} \mathrm{H}_{\text {endo- }}-}\right.$
Ar), $3.20\left(\mathrm{~s}, 12 \mathrm{H}, \mathrm{CH}_{3} \mathrm{~N}(\mathrm{C}(=\mathrm{O}))_{2}\right), 3.27\left(\mathrm{~d}, 12 \mathrm{H},{ }^{3} \mathrm{~J}(\mathrm{PH})=\right.$ $\left.9.78 \mathrm{~Hz},\left(\mathrm{C}^{2} \mathrm{H}_{3}\right) \mathrm{NP}\right), 3.77-4.11\left(\mathrm{~m}, 32 \mathrm{H}, \mathrm{OCH}_{\mathrm{a}} \mathrm{H}_{\mathrm{b}} \mathrm{CH}_{\mathrm{c}} \mathrm{H}_{\mathrm{d}} \mathrm{O}\right)$, $4.73\left(\mathrm{~d}, 8 \mathrm{H},{ }^{2} \mathrm{~J}(\mathrm{HH})=11.57 \mathrm{~Hz}, \mathrm{Ar}-\mathrm{CH}_{\mathrm{exo}} \mathrm{H}_{\mathrm{endo}}-\mathrm{Ar}\right), 5.34(\mathrm{~s}$, $\left.4 \mathrm{H}, \mathrm{CH}_{2} \mathrm{Cl}_{2}\right), 5.58(\mathrm{t}, 16 \mathrm{H}, \mathrm{HC}=\mathrm{CH}$ of $\mathrm{COD}), 6.75(\mathrm{~s}, 16 \mathrm{H}$, aromatic $\mathrm{H}) \cdot{ }^{13} \mathrm{C}-\mathrm{NMR}\left(\mathrm{CD}_{2} \overline{\mathrm{Cl}}_{2}\right): \delta(\mathrm{ppm})=28.34\left(\mathrm{~s}, \underline{\mathrm{CH}_{2}}\right.$ of COD), $31.28\left(\mathrm{~s}, \mathrm{CH}_{3} \mathrm{~N}(\mathrm{C}(=\mathrm{O}))_{2}\right), 31.40\left(\mathrm{~s}, \mathrm{C}\left(\underline{\mathrm{CH}}_{3}\right)_{3}\right), 31.80$ (d, $\left.\mathrm{PN}\left(\mathrm{CH}_{3}\right)_{2}\right), 32.13$ (s, Ar- $\left.\mathrm{CH}_{2}-\mathrm{Ar}\right), 34.20\left(\mathrm{~s}, \underline{\mathrm{C}}\left(\mathrm{CH}_{3}\right)_{3}\right)$, $66.85\left(\mathrm{~s}, \mathrm{CH}_{2} \mathrm{Cl}_{2}\right), 72.70\left(\mathrm{~s}, \mathrm{ArOCH}{ }_{2}\right), 74.40\left(\mathrm{~d},{ }^{2} \mathrm{~J}(\mathrm{PC})=3.8\right.$ $\left.\mathrm{Hz}, \mathrm{OCH}_{2} \mathrm{CH}_{2} \mathrm{OP}\right), 124.27-146.77\left(\mathrm{~m}, \mathrm{C}_{6} \mathrm{H}_{2}\right), 150.11$ and $151.63(2 \mathrm{~s}, 16 \mathrm{C}, \mathrm{C}(=\mathrm{O})) \cdot{ }^{31} \mathrm{P}-\mathrm{NMR}\left(\mathrm{CDCl}_{3}\right): \delta(\mathrm{ppm})=60.40$ $\left(\mathrm{t},{ }^{1} \mathrm{~J}(\mathrm{PPt})=2755.62 \mathrm{~Hz}\right)$. IR $(\mathrm{KBr}): \mathrm{v}\left(\mathrm{PtCl}_{2}\right)=305.7 \mathrm{~cm}^{-1}, \mathrm{v}$ $(\mathrm{C}=\mathrm{O})=1722$ and $1680 \mathrm{~cm}^{-1}$. FAB-MS: $\mathrm{m} / \mathrm{z}(\%): 4098(8)$ $\left[\mathrm{M}^{+}\right], 4063(100)\left[\mathrm{M}^{+}-\mathrm{Cl}\right], 2049$ (100) $\left[\mathrm{M}^{+} / 2-\mathrm{C}\right], 2013$ (75) $\left[\mathrm{M}^{+} / 2-\mathrm{Cl}\right] . \mathrm{C}_{144} \mathrm{H}_{208} \mathrm{Cl}_{8} \mathrm{~N}_{24} \mathrm{O}_{32} \mathrm{P}_{8} \mathrm{Pt}_{4} \times \mathrm{C}_{8} \mathrm{H}_{12}$ x $2 \mathrm{CH}_{2} \mathrm{Cl}_{2}$ (4701.76): calcd. C 45.47, H 5.57; found C 45.39, H 5.60.

\section{Compound 16}

A solution of $200 \mathrm{mg}(0.53 \mathrm{mmole})(\mathrm{COD}) \mathrm{PtCl}_{2}$ in $500 \mathrm{ml}$ $\mathrm{CH}_{2} \mathrm{Cl}_{2}$ was added dropwise to a solution of $\mathbf{1 0}(0.290 \mathrm{~g}$, $0.26 \mathrm{mmole}$ ) in dichloromethane. The reaction mixture was stirred for $16 \mathrm{~h}$ at room temperature. The solvent was removed in vacuo and the residue was washed three times with small amounts of ice cold diethyl ether and hexane to give a crystalline solid. Yield: $0.345 \mathrm{~g}(80 \%)$; dec. $148-150^{\circ} \mathrm{C}$.

${ }^{1} \mathrm{H}-\mathrm{NMR}\left(\mathrm{CD}_{2} \mathrm{Cl}_{2}\right): \delta(\mathrm{ppm})=1.09\left(\mathrm{~s}, 36 \mathrm{H}, \mathrm{C}\left(\mathrm{CH}_{3}\right)_{3}\right)$, $2.35\left(\mathrm{~m}, 16 \mathrm{H}, \mathrm{CH}_{2} \underline{\mathrm{CH}}_{2}\right.$ of COD), 3.24 and 3.36 (2d, $4 \mathrm{H}, \underline{\mathrm{H}}_{\mathrm{exo}}$, ${ }^{2} \mathrm{~J}(\mathrm{HH})=12.52$ and $\left.13.14 \mathrm{~Hz}\right), 4.08$ and $4.47\left(2 \mathrm{~d}, 4 \mathrm{H}, \mathrm{H}_{\text {endo }}\right.$, ${ }^{2} \mathrm{~J}(\mathrm{HH})=13.42$ and $\left.13.00 \mathrm{~Hz}\right), 4.11,4.16,4.56$ and $4.59(4 \mathrm{~m}$, $\left.8 \mathrm{H}, \mathrm{OCH}_{\mathrm{c}} \mathrm{H}_{\mathrm{d}} \mathrm{CH}_{\mathrm{a}} \mathrm{H}_{\mathrm{b}} \mathrm{O}\right), 4.82$ and $4.89\left(2 \mathrm{~m}, 8 \mathrm{H}, \mathrm{CH}_{\mathrm{a}} \mathrm{H}_{\mathrm{b}} \mathrm{OPF}_{2}\right)$, $5.33\left(\mathrm{~s}, 6 \mathrm{H}, \mathrm{CH}_{2} \overline{\mathrm{Cl}}_{2}\right), 5.55\left(\mathrm{t}, 8 \mathrm{H}, \underline{\mathrm{HC}}=\mathrm{CH}\right.$ of $\mathrm{COD},{ }^{-3} \mathrm{~J}(\mathrm{HH})=$ $2.16 \mathrm{~Hz}), 6.86\left(\mathrm{~s}, 8 \mathrm{H}, \mathrm{C}_{6} \underline{\mathrm{H}}_{2}\right) .{ }^{19} \mathrm{~F}-\mathrm{NMR}\left(\mathrm{CD}_{2} \mathrm{Cl}_{2}\right): \delta(\mathrm{ppm})=$ - 41.35 (dddt, ${ }^{1} \mathrm{~J}(\mathrm{FP})=1246.50 \mathrm{~Hz},{ }^{2} \mathrm{~J}\left({ }^{19} \mathrm{~F}^{195} \mathrm{Pt}\right)=616.20 \mathrm{~Hz}$, $\left.{ }^{3} \mathrm{~J}(\mathrm{FP})=25.97 \mathrm{~Hz},{ }^{4} \mathrm{~J}(\mathrm{FF})=15.38 \mathrm{~Hz}\right) .{ }^{31} \mathrm{P}-\mathrm{NMR}\left(\mathrm{CD}_{2} \mathrm{Cl}_{2}\right): \delta$ $(\mathrm{ppm})=73.07\left(\mathrm{ddtt},{ }^{1} \mathrm{~J}(\mathrm{PF})=3074.91 \mathrm{~Hz},{ }^{1} \mathrm{~J}\left({ }^{31} \mathrm{P}^{195} \mathrm{Pt}\right)=\right.$ $2504.30 \mathrm{~Hz},{ }^{2} \mathrm{~J}(\mathrm{PP})=25.00 \mathrm{~Hz},{ }^{3} \mathrm{~J}(\mathrm{PF})=17.70 \mathrm{~Hz}$. IR $(\mathrm{KBr})$ : $v\left(\mathrm{PtCl}_{2}\right)=280$ and $319 \mathrm{~cm}^{-1}, v_{(\text {as }}(\mathrm{PF})=790 \mathrm{~cm}^{-1}, v_{(\mathrm{s})}(\mathrm{PF})=$ $899 \mathrm{~cm}^{-1} . \mathrm{C}_{52} \mathrm{H}_{68} \mathrm{Cl}_{4} \mathrm{~F}_{8} \mathrm{O}_{8} \mathrm{P}_{4} \mathrm{Pt}_{2} \times 2 \mathrm{C}_{8} \mathrm{H}_{12} \times 3 \mathrm{CH}_{2} \mathrm{Cl}_{2}$ (1629.04): calcd. C 40.60, H 4.70; found C 40.69, H 4.65.

\section{REFERENCES}

1. C. Floriani, D. Jacoby, A. Chiesi-Villa and C. Guastini, Angew. Chem., 1989, 101, 1430-1431; Angew. Chem. Int. Ed. Engl. 1989, 28, 1376-1377.

2. D. V. Khasnis, M. Lattman and C. D. Gutsche, J. Am. Chem. Soc., 1990, 112, 9422-9426.

3. F. Grynszpan, O. Aleksiuk and S. E. Biali, J. Chem. Soc. Chem. Commun., 1993, 13-18.

4. J. Gloede, B. Costisella, M. Ramm and R. Bienert, Phosphorus, Sulfur \& Silicon, 1993, 84, 217-222.

5. I. Shevchenko, H. Zhang and M. Lattman, Inorg. Chem., 1995, 34, 5405-5409.

6. L. N. Markovsky, M. A. Visotsky, V. V. Pirozhenko, V. I. Kalchenko, J. Lipkowski and Y. A. Simonov, Chem. Commun., 1996, 69-74.

7. J. K. Moran and D. M. Roundhill, Inorg. Chem. 1992, 31, 4213-4215.

8. M. Heiko Franz, R. Birzoi, C. Vasile Maftei, E. Maftei, G. Kelter, H. Herbert Fiebig and I. Neda, Amino Acids, 2018, 50, 163-188.

9. M. Heiko Franz, M. Iorga, C. Vasile Maftei, E. Maftei, I. Neda, Amino Acids, 2019, 52, 55-72.

10. I. Neda, H.-J. Plinta, R. Sonnenburg, A. Fischer, P. G. Jones and R. Schmutzler, Chem. Ber., 1995, 128, 267-273. 
11. I. Neda, H.-J. Plinta, A. Fischer, P. G. Jones and R. Schmutzler, Phosphorus, Sulfur \& Silicon, 1996, 109110, 113-116.

12. T. Siedentop, I. Neda, H. Thönnessen, P. G. Jones, R. Schmutzler and Z. Naturforsch., 1999, 54b, 761-766.

13. I. Neda, A. Volbrecht, J. Grunenberg and R. Schmutzler, Heteroatom Chem., 1998, 9, 553-558.

14. C. B. Dieleman, D. Matt, I. Neda, R. Schmutzler, H. Thönnessen, P. G. Jones and A. Harriman, J. Chem. Soc., Dalton Trans., 1998, 2115-2118.

15. I. Neda, P. Sakhaii, A. Waßmann, U. Niemeyer, E. Günther and J. Engel, Synthesis, 1999, 1625-1632.

16. C. Kunze, D. Selenit, I. Neda, R. Schmutzler, A. Spannenberg and A. Börner, Hetroatom Chem., 2001, $12,577-580$

17. C. V. Maftei, E. Fodor, P. G. Jones, M. H. Franz, C. M. Davidescu and I. Neda, Pure Appl.Chem., 2015 , 87, 415-419.

18. S. Shinkai, Tetrahedron 1993, 49, 8933-8968.

19. M. Kawaguchi, A. Ikeda, S. Shinkai and I. Neda, J. Inclusion Phenom. Mol. Recognit.,Chem., 2000, 37, 253-256.

20. C. B. Dieleman, D. Matt, I. Neda, R. Schmutzler, A. Hareiman and R. Yaftian, Chem. Commun., 1999, 1911-1916.

21. D. Jacoby, C. Floriani, A. Chiesi-Villa and C. Rizzoli, J. Chem. Soc. Dalton Trans., 1993, 813-814.

22. B. Masci, Tetrahedron 1995, 51, 5459-5464.

23. K. Araki, K. Inada and S. Shinkai, Angew. Chem. 1996, 108, 92-94; Angew. Chem. Int. Ed. Engl. 1996, 35, $72-74$.

24. P. Timmermann, K. G. A. Nierop, E. A. Brinks, W. Verboom, F. C. J. M. van Veggel, W. P. van Hoorn and D. N. Reinhoudt, Chem. Eur. J. 1995, 1, 135-143.

25. P. D. Hampton, W. Tong, S. Wu and E. N. Duesler, J. Chem. Soc., Perkin. Trans. 1996, 1127-1130.

26. B. König, M. Rödel, P. Bubenitschek, P. G. Jones and I. Thondorf, J. Org. Chem. 1995, 60, 7406-7410.

27. B. König, Chem. Ber., 1997, 130, 421-423.

28. W. Xu, J. P. Rouke, J. J. Vittal and R. J. Puddephatt, Inorg. Chem., 1995, 34, 323-329.

29. D. M. Roundhill, Prog. Inorg. Chem., 1995, 43, 533-592.

30. A. Marra, A. Dondoni and F. Sansone, J. Org. Chem., 1996, 61, 5155-5158.

31. S. J. Meunier and R. Roy, Tetrahedron Lett., 1996, 37, $5469-5472$

32. X. Yang, D. McBranch, B. Swanson and DeQuan Li, Angew. Chem., 1996, 108, 572-575; Angew. Chem. Int. Ed. Engl., 1996, 35, 538-540.

33. B. Xu and T. M. Swager, J. Am. Chem. Soc., 1993, 115, $1159-1160$.

34. D. Diamond and M. A. McKervey, Chem. Soc. Rev., 1996, 25, 15-24.

35. Y. Kubo, S. Maeda, S. Tökita and M. Kubo, Nature, 1996, 382, 522-524.

36. T. H. Webb and C. S. Wilcox, Chem. Soc. Rev. 1993, 22, 383-395.

37. C. Loeber, D. Matt, P. Priard and D. Grandjean, J. Chem. Soc. Dalton Trans., 1996, 513-524.

38. C. Loeber, C. Wieser, D. Matt, A. Decian, J. Fischer and L. Toupert, Bull. Chem. Soc. Chim. France, 1995, 132, 166-177.

39. D. Matt, C. Loeber, J. Vicens and Z. Asfari, J. Chem. Soc. Chem. Commun., 1993, 604-606.

40. A. Vollbrecht, I. Neda and R. Schmutzler, Phosphorus, Sulfur \& Silicon, 1995, 107, 173-179.

41. A. Vollbrecht, I. Neda, H. Thönnessen, P. G. Jones, R. K. Harris, L. A. Crowe and R. Schmutzler, Chem. Ber., 1997, 130, 1715-1720.
42. M. Stolmar, C. Floriani, A. Chiesi-Villa and C. Rizzoli, Inorg. Chem., 1997, 36, 1694-1701.

43. C. H. Agris, K. R. Blake, P. S. Miller and M. P. Reddy, Biochemistry, 1986, 25, 6268-6275.

44. B. Rosenberg, L. van Camp, J. E. Trasko and V. H. Mansour, Nature, 1969, 222, 385-386.

45. K. Iwamoto, K. Araki and S. Shinkhai, J. Org. Chem., 1991, 56, 4955-4962.

46. C. D. Gutsche, "Calixarenes", The Royal Society of Chemistry, Cambridge, England, 1989.

47. Y. Aoyama, Y. Tanaka, H. Toi and H. Ogoshi, J. Am. Chem. Soc., 1988, 110, 634-635.

48. C. Jaime, J. de Mendoza, P. Prados, P. M. Nieto and C. Sanchez, J. Org. Chem., 1991, 56, 3372-3376.

49. J. K. Moran, E. M. Georgiev, A. T. Yordanov, J. T. Mague and D. M. Roundhill, J. Org. Chem., 1994, 59, 5990-5998.

50. B. W. Krüger, "Investigations on difluorophosphorus (III) compounds" Ph.D. Thesis, Technische Universität Braunschweig, 1978.

51. T. G. Meyer, A. Fischer, P. G. Jones and R. Schmutzler, Z. Naturforsch., 1993, 48b, 659-671.

52. P. W. Atkins, "Physikalische Chemie", 1. Aufl., VCH Weinheim, 1990, p. $831 \mathrm{ff}$.

53. I. Neda, M. Farkens and R. Schmutzler., Z. Naturforsch., 1994, 49b, 165-170.

54. M. Fujta, S. Nagao and K. Ogura, J. Am. Chem. Soc., 1995, 117, 1649-1650.

55. P. N. W. Baxter, J.-M. Lehn, A. Decian and J. Fischer, Angew. Chem., 1993, 105, 92-95; Angew. Chem. Int. Ed. Engl., 1993, 32, 69-72.

56. P. Jacopozzi and E. Dalcanale, Angew. Chem., 1997, 109 , 665-667; Angew. Chem. Int. Ed. Engl., 1997, 36, 613-615.

57. P. S. Pregosin and R. W. Kunz, ${ }^{631} \mathrm{P}-$ and ${ }^{13} \mathrm{C}-\mathrm{NMR}$ of Transition Metal Phosphine Complexes", P. Diehl, E. Fluck and R. Kosfeld (Eds.), Springer Verlag, Heidelberg, 1979.

58. F. Kober, "Grundlagen der Komplexchemie", 1 Auflage, Verlag Salle und Sauerländer, Frankfurt am Main, Berlin, München, Aarau, Salzburg, 1979, p. 235-242.

59. H. C. Clark and L. E. Manzer, J. Organomet. Chem., 1973, 59, 411-428.

60. C. H. Dungan and J. R. van Wazer, "Compilation oft he Reported ${ }^{19}$ F-NMR Chemical Shifts", John Wiley \& Sons, New York, London, Sydney, Toronto, 1970.

61. T. G. Meyer, P. G. Jones and R. Schmutzler, Z. Naturforsch., 1992, 47b, 517-525.

62. I. Neda, T. Kaukorat, R. Schmutzler, U. Niemeyer, B. Kutscher, J. Pohl and J. Engel, Phosphorus, Sulfur, and Silicon, 2000, 162, 81-218.

63. A. Kadyrov, I. Neda, T. Kaukorat, R. Sonnenburg, A. Fischer, P. G. Jones and R. Schmutzler, Chem. Ber., 1996, 129, 725-732

64. I. Neda, M. Farkens, A. Fischer, P. G. Jones and R. Schmutzler, Zeitschrift für Naturforschung - Section B J. of Chem. Sci., 1993, 48, 860-866.

65. W. Albers, W. Krüger, W. Storzer and R. Schmutzler, Synth React. Inorg. Met.-Org. Chem., 1985, 15, 187-195.

66. C. Kunze, I. Neda, M. Freitag, P. G. Jones and R. Schmutzler, Z. Anorg. Allg. Chem., 2002, 628, 545.

67. I. Neda, H.-J. Plinta, A. Fischer, P.G. Jones and R. Schmutzler, Phosphorus, Sulfur, and Silicon, 1996, 109/110, 113.

68. P. Sakhaii, I. Neda, M. Freytag, H. Thönnessen, P. G. Jones and R. Schmutzler, Z. Anorg. Allg. Chem., 2000, 626, 1246

69. C. Kunze, D. Selent, I. Neda, M. Freytag, P. G. Jones, R. Schmutzler, W. Baumann and A. Börner, Z. Anorg. Allg. Chem., 2002, 628, 779-787. 
